\title{
Article \\ Confirming the Molecular Basis of the Solvent Extraction of Cadmium(II) Using 2-Pyridyl Oximes through a Synthetic Inorganic Chemistry Approach and a Proposal for More Efficient Extractants
}

\author{
Anastasia Routzomani ${ }^{1}$, Zoi G. Lada ${ }^{1,2}$ (), Varvara Angelidou ${ }^{1}$, Catherine P. Raptopoulou ${ }^{3}$ (D), \\ Vassilis Psycharis ${ }^{3, *}\left(\mathbb{D}\right.$, Konstantis F. Konidaris ${ }^{4, *}$, Christos T. Chasapis ${ }^{2,5, * \mathbb{C}}$ and Spyros P. Perlepes ${ }^{1,2, *}$
}

1 Department of Chemistry, University of Patras, 26504 Patras, Greece; a.routzomani@gmail.com (A.R.); zoilada@iceht.forth.gr (Z.G.L.); varvara_angelidou@hotmail.com (V.A.)

2 Institute of Chemical Engineering Sciences (ICE-HT), Foundation for Research and Technology-Hellas (FORTH), Platani, P.O. Box 1414, 26504 Patras, Greece

3 Institute of Nanoscience and Nanotechnology, NCSR "Demokritos", Aghia Paraskevi, Attikis, 15310 Athens, Greece; c.raptopoulou@inn.demokritos.gr

4 Department of Science and High Technology and INSTM, University of Insubria, 22100 Como, Italy

5 NMR Facility, Instrumental Analysis Laboratory, School of Natural Sciences, University of Patras, 26504 Patras, Greece

check for updates

Citation: Routzomani, A.; Lada, Z.G.; Angelidou, V.; P. Raptopoulou, C.; Psycharis, V.; Konidaris, K.F.; Chasapis, C.T.; Perlepes, S.P. Confirming the Molecular Basis of the Solvent Extraction of Cadmium(II) Using 2-Pyridyl Oximes through a Synthetic Inorganic Chemistry Approach and a Proposal for More Efficient Extractants. Molecules 2022, 27, 1619. https://doi.org/10.3390/ molecules27051619

Academic Editor: James Barker

Received: 4 February 2022

Accepted: 24 February 2022

Published: 28 February 2022

Publisher's Note: MDPI stays neutral with regard to jurisdictional claims in published maps and institutional affiliations.

Copyright: (C) 2022 by the authors. Licensee MDPI, Basel, Switzerland. This article is an open access article distributed under the terms and conditions of the Creative Commons Attribution (CC BY) license (https:// creativecommons.org/licenses/by/ $4.0 /)$.
* Correspondence: v.psycharis@inn.demokritos.gr (V.P.); konstantis.konidaris@uninsubria.it (K.F.K.); cchasapis@upatras.gr (C.T.C.); perlepes@patreas.upatras.gr (S.P.P.); Tel.: +30-210-650-3346 (V.P.); +39-031-238-6472 (K.F.K.); +30-261-0 99-6261 (C.T.C.); +30-261-099-6730 (S.P.P.)

\begin{abstract}
The present work describes the reactions of $\mathrm{CdI}_{2}$ with 2-pyridyl aldoxime (2paoH), 3-pyridyl aldoxime (3paoH), 4-pyridyl aldoxime $(4 \mathrm{paoH}), 2$-6-diacetylpyridine dioxime $\left(\mathrm{dapdoH}_{2}\right)$ and 2,6-pyridyl diamidoxime $\left(\mathrm{LH}_{4}\right)$. The primary goal was to contribute to understanding the molecular basis of the very good liquid extraction ability of 2-pyridyl ketoximes with long aliphatic chains towards toxic $\mathrm{Cd}(\mathrm{II})$ and the inability of their 4-pyridyl isomers for this extraction. Our systematic investigation provided access to coordination complexes $\left[\mathrm{CdI}_{2}(2 \mathrm{paoH})_{2}\right](\mathbf{1}),\left\{\left[\mathrm{CdI}_{2}(3 \mathrm{paoH})_{2}\right]\right\}_{\mathrm{n}}(\mathbf{2})$, $\left\{\left[\mathrm{CdI}_{2}(4 \mathrm{paoH})_{2}\right]\right\}_{\mathrm{n}}(3)$ and $\left[\mathrm{CdI}_{2}\left(\right.\right.$ dapdoH$\left.\left._{2}\right)\right](4)$. The reaction of $\mathrm{CdI}_{2}$ and $\mathrm{LH}_{4}$ in EtOH resulted in a $\mathrm{Cd}(\mathrm{II})$-involving reaction of the bis(amidoxime) and isolation of $\left[\mathrm{CdI}_{2}\left(\mathrm{~L}^{\prime} \mathrm{H}_{2}\right)\right](5)$, where $\mathrm{L}^{\prime} \mathrm{H}_{2}$ is the new ligand 2,6-bis(ethoxy)pyridine diimine. A mechanism of this transformation has been proposed. The structures of 1, 2, 3, 4.2EtOH and 5 were determined by single-crystal X-ray crystallography. The complexes have been characterized by FT-IR and FT-Raman spectra in the solid state and the data are discussed in terms of structural features. The stability of the complexes in DMSO was investigated by ${ }^{1} \mathrm{H}$ NMR spectroscopy. Our studies confirm that the excellent extraction ability of 2-pyridyl ketoximes is due to the chelating nature of the extractants leading to thermodynamically stable $\mathrm{Cd}(\mathrm{II})$ complexes. The monodentate coordination of 4-pyridyl ketoximes (as confirmed in our model complexes with $4 \mathrm{paoH}$ and $3 \mathrm{paoH}$ ) seems to be responsible for their poor performance as extractants.
\end{abstract}

Keywords: cadmium(II); coordination chemistry; pyridyl oximes as ligands; single crystal X-ray structures; spectroscopic studies

\section{Introduction}

Organic matter and heavy toxic metals are the main pollutants of wastewaters, the threat from the latter being more serious [1-6]. This is due to the non-biodegradable and non-decomposable nature of the toxic metals, making the development of efficient approaches for their removal and uptake extremely important [7]. Methods in action involve chemical precipitation, microbial treatment, electrodeposition, reverse osmosis, physical/chemical adsorption and solvent extraction [1,8-12]. Solvent extraction is very useful for base metal recovery; the desired metal ions are transferred selectively (after 
the ore is leached into an aqueous solution) to an $\mathrm{H}_{2} \mathrm{O}$-immiscible phase with ligands as ion-exchangers, which release an equivalent number of $\mathrm{H}_{3} \mathrm{O}^{+}$ions back to the aqueous feed solution [13]. For the removal of toxic metal ions from aqueous environments, a special method of solvent extraction, named liquid-liquid extraction, is common [12]. Three types of liquid-liquid extraction are currently used. All three involve the metal-ion association with an organic complexant (extractant) to form a species that is transferred from the aqueous to the organic phase in a two-phase system [12]. In the first type, both the complexant and the metal ion are soluble in the organic phase. In the second type, the complexant and the metal ion source are insoluble in the aqueous phase, the complexation reaction occurs at the interphase region and the metal species is then transferred into the organic phase. In the third type of liquid-liquid extraction, the extractant is soluble in the organic phase (hexane, kerosene, and chloroform for laboratory experiments) and the source of the metal ion is soluble only in the aqueous phase; after the complexation reaction that occurs at the interphase surface, the metal-extractant coordination complex is transferred into the organic phase. The present model study refers to the latter type of liquid-liquid extraction. Most efficient extractants include chelating or even macrocyclic ligands [12]. Today, it is firmly established that an effective extractant should [14]: (a) selectively coordinate to the toxic metal ion having no or very weak affinity for alkali and alkaline metal ions (e.g., $\mathrm{Na}^{+}, \mathrm{Ca}^{2+}$, etc.) which are present at higher concentrations in waste and natural waters; (b) give somewhat thermodynamically stable complex with the toxic metal ion; (c) have fast kinetics with the metal ion to be extracted; (d) resist hydrolysis; and (e) result in a reversible complexation allowing for the easy and complete recovery of the metal ion without destruction or decomposition of the extractant.

The history of cadmium was brilliant in the past $[15,16]$. Contrary to the past, the present and future of cadmium (both as element and +2 cation) seem dark. Cd is a very toxic metal and is considered as one of the 13 most dangerous metals by the Environmental Protection Agency (EPA) in the U.S. [17,18]. Its ion has generally a short life span and is rendered inert after a period of action. The maximum limit of $\mathrm{Cd}(\mathrm{II})$ for humans in $\mathrm{H}_{2} \mathrm{O}$ is $10 \mathrm{mg} \mathrm{L}^{-1}$. It is introduced into the environment by metallurgical processes (e.g., $\mathrm{Pb}-\mathrm{Zn}$ mining) and wastes from electroplating and companies producing pigments, materials for photography and alkaline batteries [1,2,15,19-21]. Exposure to $\mathrm{Cd}(\mathrm{II})$ causes damages in heart, bones, lungs, and mainly in the kidneys where it is collected affecting their filtering ability [22]. Cadmium(II) compounds are widely classified as carcinogens for humans; most data come from detailed studies which have proven that occupational exposure to $\mathrm{Cd}(\mathrm{II})$ sources is closely associated with lung cancer, and possibly to human prostate and renal cancers [23]. Thus, methods for Cd(II) uptake from wastewaters are becoming more and more important.

In the liquid-liquid extraction of toxic $\mathrm{Cd}(\mathrm{II})$, several extractants have been used including EDTA derivatives, organophosphorus compounds, dithiocarbamates, crown ethers, calix[4]arene derivatives, 8-quinolols, pyridine carboxamides and pyridyl oximes [12,24]. The stimulus of the present work and a previous publication from our groups [14] was an excellent liquid-liquid extraction study of $\mathrm{Cd}(\mathrm{II})$ from aqueous chloride solutions using 1-(2-pyridyl)tridecane-1-one (2PC12), 1-(2-pyridyl)-pentadecane-1-one (2PC14), 1-(4-pyridyl)-tridecane-1-one (4PC12) and 1-(4-pyridyl)-pentadecane-1-one (4PC14) oximes [25], Figure 1. We are doing a parenthesis here to mention that 2PC12, among other 2-pyridyl ketoximes, has also been successfully used for the liquid-liquid extraction of copper(II) from aqueous solutions containing $\mathrm{Cl}^{-}$ions [26]. Parus, A. et al. examined carefully the influence of extractant, $\mathrm{Cd}(\mathrm{II})$ and $\mathrm{Cl}^{-}$ concentrations, and the nature of several polar and non-polar organic solvents (diluents) on the extraction efficiency. The study revealed two general experimental facts: (a) Cd(II) is extracted using only 2PC12 and 2PC14. 4PC12 and 4PC14 did not transport complexes with Cd(II) to organic phases. The organic phase employed was $\mathrm{CHCl}_{3}$ or hydrocarbons mixed with decan1-ol. The metal ion was stripped from the loaded organic phase with $\mathrm{H}_{2} \mathrm{O}$ and aqueous $\mathrm{NH}_{3}$ solutions; and (b) Based on the effect of the varying concentrations of 2PC12 and 2PC14 on the extraction capability, it was proposed that the chemical species formed and transferred into 
the organic phase are the neutral complexes $\left[\mathrm{CdCl}_{2}(2 \mathrm{PC} 12)_{2}\right]$ and $\left[\mathrm{CdCl}_{2}(2 \mathrm{PC} 14)_{2}\right]$. Using a synthetic coordination chemistry approach [14], we proved that such complexes are capable of existence. The primary goal of the present study was to contribute in understanding the molecular basis of the experimental fact (a) mentioned above. Although the reason of the superior extraction capability of 2PC12, 2PC14 compared to those of 4PC12, 4PC14 might be obvious, i.e., the formation of stable 5-membered chelating rings with the $\mathrm{N}$-donor atoms of the former extractants - which give a thermodynamic stability of the complexes in solution-and the inability of chelating behavior in the case of 4PC12, 4PC14, we were interested in providing synthetic and structural evidence for this working with model complexes. Thus, we used the three isomers of pyridyl aldoximes (2-pyridyl aldoxime, 2paoH; 3-pyridyl aldoxime, 3paoH; 4-pyridyl aldoxime, 4paoH), Figure 1, which gave crystalline complexes. The compounds 2paoH and 4 paoH are somewhat satisfactory analogs (albeit not ideal ones) of the extractants 2PC12, 2PC14 and 4PC12, 4PC14, respectively. The main difference is the presence of a long aliphatic (hence hydrophobic) chain in the real extractants instead of the - $\mathrm{CHNOH}$ group in the ligands. Cadmium(II) complexes with the ligand $3 \mathrm{paoH}$ were also studied. This paper describes results from the synthetic investigation of the general reaction systems $\mathrm{CdI}_{2} / 2 \mathrm{paoH}$, $\mathrm{CdI}_{2} / 3$ paoH and $\mathrm{CdI}_{2} / 4$ paoH. For consistency reasons, we used the same inorganic anion of the $\mathrm{Cd}$ (II) source; although we originally worked with $\mathrm{CdCl}_{2} \cdot 2 \mathrm{H}_{2} \mathrm{O}$ to better simulate the real extraction conditions (e.g., chloride solutions), $\mathrm{CdI}_{2}$ gave better crystallinity of the products and their structures were solved through single crystal X-ray crystallography (vide infra).<smiles>CC/C(=N\O)c1ccccn1</smiles><smiles>CCC(=NO)c1ccncc1</smiles><smiles>O/N=C/c1ccccn1</smiles>

$$
\begin{aligned}
& n=11,2 \text { PC } 12 \\
& n=13,2 \text { PC } 14
\end{aligned}
$$

$$
\begin{aligned}
& \mathrm{n}=11,4 \mathrm{PC} 12 \\
& \mathrm{n}=13,4 \mathrm{PC} 14
\end{aligned}
$$

$2 \mathrm{paoH}$<smiles>O/N=C/c1cccnc1</smiles>

3 paoH<smiles>O/N=C/c1ccncc1</smiles>

$4 \mathrm{paoH}$<smiles>C/C(=N\O)c1cccc(/C(C)=N/O)n1</smiles>

dapdoH $_{2}$<smiles>N/C(=N\O)c1cccc(/C(N)=N/O)n1</smiles>

$\mathrm{LH}_{4}$

Figure 1. Structural formulae of the extractants and the ligands discussed in the text, and their abbreviations; the presence of four hydrogens in the abbreviation of 2,6-pyridyl diamidoxime $\left(\mathrm{LH}_{4}\right)$ implies the known in the literature possibility of the single deprotonation of the $-\mathrm{NH}_{2}$ group [27].

A secondary goal of this work was to propose types of ligands that might be better extractants than the 2-pyridyl ketoximes 2PC12 and 2PC14. For this reason, we performed reactions of $\mathrm{CdI}_{2}$ with 2,6-diacetylpyridine dioxime (dapdoH $\mathrm{H}_{2}$, Figure 1) and 2,6-diacetylpyridine diamidoxime $\left(\mathrm{LH}_{4}\right.$, Figure 1$)$, to investigate whether the potentially 
$\mathrm{N}$ (pyridyl), $\{\mathrm{N} \text { (oxime) }\}_{2}$ tridentate chelating character of these ligands could be realized; in such a case, molecules analogous to dapdoH $\mathrm{H}_{2}$ and $\mathrm{LH}_{4}$ might be better extractants for $\mathrm{Cd}(\mathrm{II})$. The ligand $\mathrm{LH}_{4}$ possesses two amidoxime moieties which, when introduced in materials (e.g., polymers) give excellent adsorbents for the efficient recovery of $\mathrm{Cd}(\mathrm{II})$ from aqueous media $[1,21,28]$.

The spectroscopic studies and the structures of the prepared complexes emphasize the importance of the information emerging from synthetic investigations that otherwise would not have been revealed through exclusively solution studies, while simultaneously shedding light onto the connection of the requisite chemistry with the removal of toxic Cd(II) using pyridyl oxime extractants [19]. The present work can be considered as a continuation of our intense interest in the coordination chemistry of pyridyl aldo/ketoximes and dioximes, and amidoximes/amidodioximes $[14,27,29-40]$ and on various aspects of Cd(II) chemistry [14,40-45].

\section{Results and Discussion}

\subsection{Comments on the Syntheses of the Complexes}

Since the $\mathrm{pH}$ of the aqueous phases during the real extraction experiments was $\sim 4.0$ and the extractants were neutral, we avoided adding external bases (e.g., $\mathrm{OH}^{-}, \mathrm{Et}_{3} \mathrm{~N}$, etc.) which would deprotonate the ligands used. The optimized reaction systems used are conveniently summarized in Figure 2.

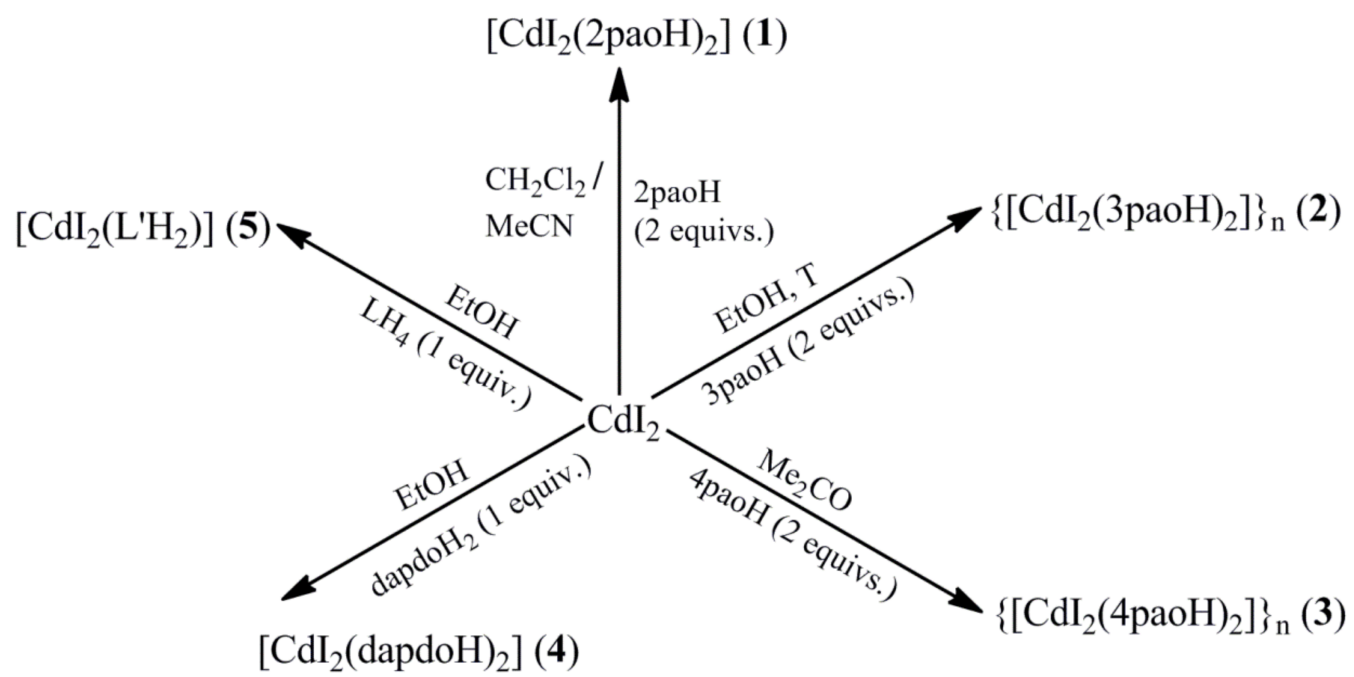

Figure 2. Optimized experimental reaction conditions that lead to $\mathrm{Cd}(\mathrm{II})$ complexes (1-5); the lattice EtOH molecules in the dapdoH $\mathrm{H}_{2}$ complex are not shown. The structural formula of the ligand $\mathrm{L}^{\prime} \mathrm{H}_{2}$ and a possible mechanism of the $\mathrm{LH}_{4} \rightarrow \mathrm{L}^{\prime} \mathrm{H}_{2}$ transformation are presented in Figure 3 (vide infra).

The reaction schemes illustrated in Figure 2 deserve synthetic comments. Thus: (i) The use of $1: 1$ reaction ratio in the case of the $\mathrm{CdI}_{2} /(2,3,4)$ paoH systems (the complexes were isolated using 1:2 reaction ratios, which coincide with their stoichiometries) does not affect the product identity, leading again to compounds 1-3 (microanalytical and IR evidences). (ii) Complexes 2,3 can be precipitated from $\mathrm{MeCN}$ solutions (IR evidence), but their crystallinity is lower compared to that using $\mathrm{EtOH}$ and $\mathrm{Me}_{2} \mathrm{CO}$ as solvents, respectively. (iii) The use of excess dapdoH $\mathrm{H}_{2}$ in its reaction with $\mathrm{CdI}_{2}$ (e.g., a 2:1 dapdoH $\mathrm{H}_{2}: \mathrm{CdI}_{2}$ ratio) does not affect the product identity (IR and Raman evidences); the complex was originally isolated using the 1:1 reaction which coincides with its stoichiometry. However, if the reaction solution is concentrated enough (to increase the low yield), the solid product is contaminated with free ligand; and (iv) The study of the $1: 1 \mathrm{CdI}_{2} / \mathrm{LH}_{4}$ reaction system in $\mathrm{EtOH}$ provided us with surprising results. The initially precipitated solid (in a yield of $\sim 10 \%$ ) was analyzed perfectly as $\left[\mathrm{CdI}_{2}\left(\mathrm{LH}_{4}\right)\right](\mathbf{5 a})$, as expected. The identity of the product was confirmed by its IR and ${ }^{1} \mathrm{H}$ NMR spectra (vide infra). Despite our intense efforts, 
we could not grow crystals of $\mathbf{5 a}$ for detailed structural characterization. Somewhat to our surprise, an unexpected experimental result was observed during the storage of the filtrate at room temperature; within four days, its color turned slowly pale violet! The pale violet solution was kept in the refrigerator $\left(\sim 5^{\circ} \mathrm{C}\right)$ and $\mathrm{X}$-ray quality, colorless crystals of $\left[\mathrm{CdI}_{2}\left(\mathrm{~L}^{\prime} \mathrm{H}_{2}\right)\right]$ (5) were grown in a $\sim 40 \%$ yield (based on the initially used metal source) within one week. Single-crystal X-ray crystallography revealed that 5 contained the transformed ligand $\mathrm{L}^{\prime} \mathrm{H}_{2}$, i.e., the $\mathrm{LH}_{4} \rightarrow \mathrm{L}^{\prime} \mathrm{H}_{2}$ transformation had occurred. The free compound $\mathrm{L}^{\prime} \mathrm{H}_{2}$ is not known in organic chemistry. We do believe that the observed transformation is $\mathrm{CdI}_{2}$-promoted/assisted, since ethanolic solutions of $\mathrm{LH}_{4}$ are stable for months. The metal ion-involving reactions of the amidoxime group are well known [46] in the field of the reactivity of coordinated ligands. No analogous reaction has been observed to date in the chemistry of amidoximes. Without any detailed mechanistic studies, we propose the simplified mechanism shown in Figure 3 for the $\mathrm{LH}_{4} \rightarrow \mathrm{L}^{\prime} \mathrm{H}_{2}$ transformation. The formation of the $\mathrm{L}^{\prime} \mathrm{H}_{2}$ probably involves nucleophilic attack of the solvent to the oxime $\mathrm{C}$ atom (Cd(II) coordination to the oxime nitrogen might activate the amidoxime groups towards nucleophilic attack) followed by the reduction in the oxime group by the generated $\mathrm{HI}$, with the simultaneous production of $\mathrm{I}_{2}$; the latter justifies the observation of the pale violet color of the reaction solution. In accordance with our proposal, the transformation does not take place in $\mathrm{MeCN}$ from which a very small quantity of $\mathbf{5 a}$ is precipitated.

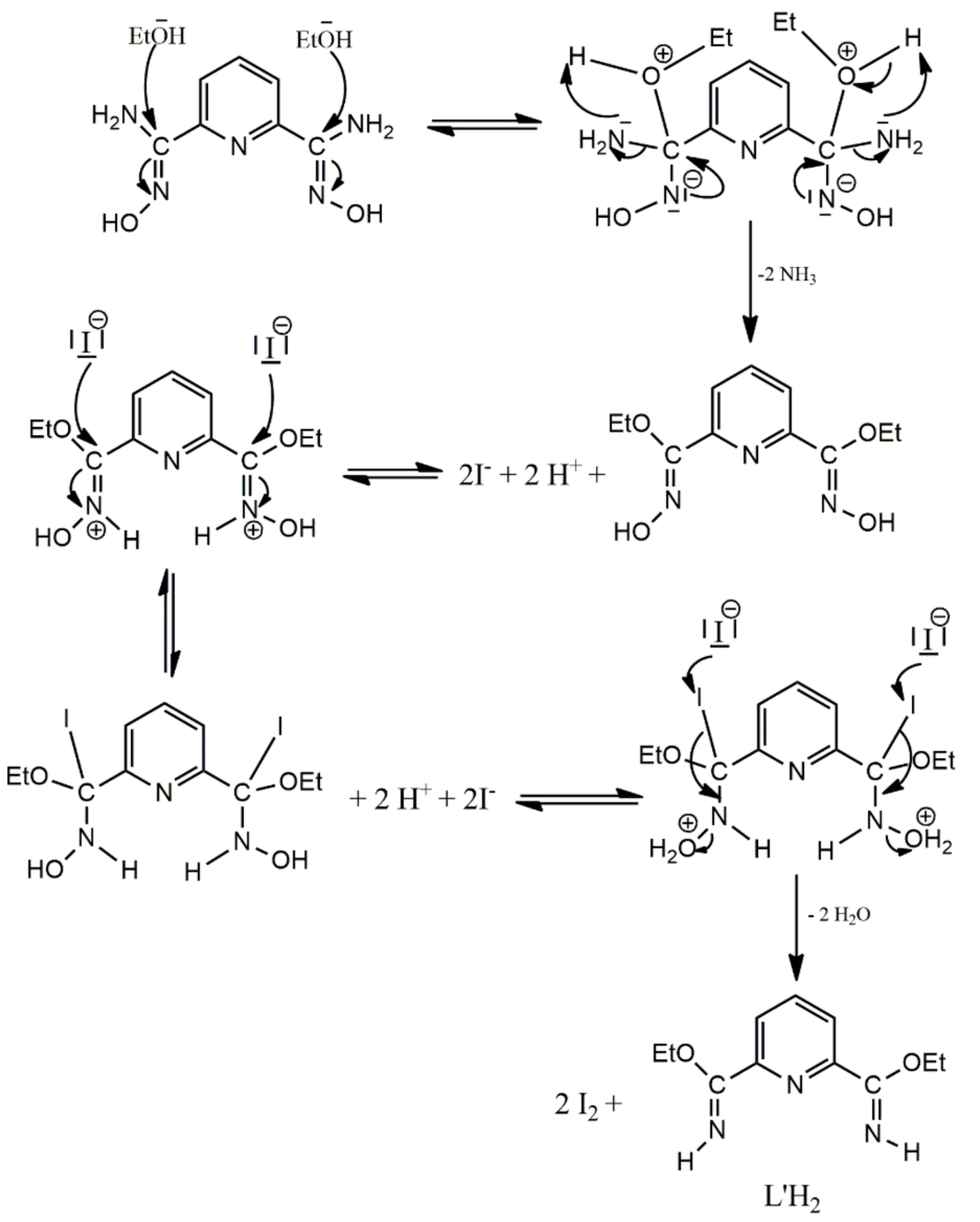

Figure 3. A simplified mechanistic proposal for the $\mathrm{CdI}_{2}$-promoted/assisted $\mathrm{LH}_{4} \rightarrow \mathrm{L}^{\prime} \mathrm{H}_{2}$ transformation. The $\mathrm{I}^{-}$ions come from the metal source, while the $\mathrm{H}^{+}$ions (as a matter of fact $\mathrm{H}_{3} \mathrm{O}^{+}$) from the first step of hydrolysis/solvolysis of $\left[\mathrm{Cd}\left(\mathrm{H}_{2} \mathrm{O}\right)_{6}\right]^{2+} /\left[\mathrm{Cd}(\mathrm{EtOH})_{6}\right]^{2+}$; the water is contained in the organic solvent which is not anhydrous. 


\subsection{Spectroscopic Characterization in Brief}

The complexes were characterized in the solid state by IR and Raman spectroscopies. Representative spectra are shown in Figure 4, Figure 5, Figure S1, Figure S2, Figure S3, Figure S4 and Figure S5. The spectra do not exhibit bands that are present in the free ligands 2paoH, $3 \mathrm{paoH}, 4 \mathrm{paoH}$, dapdoH $\mathrm{H}_{2}$ and $\mathrm{LH}_{4}$, suggesting their purity; if such bands were present, the complexes would have been contaminated with the free ligands used as starting materials. The presence of neutral oxime groups in 1, 2, 3 and 4 (well-dried unsolvated sample) is manifested by broad bands (with 2-4 submaxima in the spectra of 1 and 4) at $3400 \mathrm{~cm}^{-1}$ assigned to $v(\mathrm{OH})[38,39]$. The bands at 3444 and $3292 \mathrm{~cm}^{-1}$ in the IR spectrum of 5 reflect the existence of the imino $(=\mathrm{NH})$ groups in the complex [47]. In $\mathbf{5 a}$, the bands at $3480\left[v_{\text {as }}\left(\mathrm{NH}_{2}\right)\right], 3432\left[v_{\mathrm{s}}\left(\mathrm{NH}_{2}\right)\right]$ and $3372[v(\mathrm{OH})]$ reflect the existence of $-\mathrm{NH}_{2}$ and $-\mathrm{OH}$ groups supporting the incorporation of coordinated $\mathrm{LH}_{4}$ in the complex. The corresponding bands in the free $\mathrm{LH}_{4}$ appear at 3484,3420 and $\sim 3380 \mathrm{~cm}^{-1}$. The broadness of the $v(\mathrm{OH}), v(\mathrm{NH}), v_{\text {as }}\left(\mathrm{NH}_{2}\right)$ and $v_{\mathrm{s}}\left(\mathrm{NH}_{2}\right)$ bands, combined with their relatively low wavenumber, are both indicative of hydrogen bonding [38,39]. As expected, the $\mathrm{O}-\mathrm{H}$ and $\mathrm{N}-\mathrm{H}$ stretching vibrations are hardly seen in the Raman spectra of the complexes. The peaks at 3076-2922 $\mathrm{cm}^{-1}$ are assigned to $v(\mathrm{C}-\mathrm{H})$ vibrations [14,48,49]. The in-plane, $\delta(\mathrm{py})$, and out-of-plane, $\gamma($ py), deformation vibrations of the 2-pyridyl ring of free paoH (at 627 and $404 \mathrm{~cm}^{-1}$, respectively) shift upwards (at 646 and $466 \mathrm{~cm}^{-1}$, respectively) in 1 suggesting coordination of the ring-N atom [38]. The $\delta(\mathrm{py})$ vibration appears as a weak peak in its Raman spectrum [48]. The same trend is observed in the vibrational spectra of the other complexes. For example, the $\delta$ (py) and $\gamma\left(\right.$ py) bands are at 658 and $486 \mathrm{~cm}^{-1}$, respectively, in the IR spectrum of 3, while the corresponding vibrations in the spectrum of free 4 paoH are located at 640 and $452 \mathrm{~cm}^{-1}$, respectively. The $v(\mathrm{C}=\mathrm{N})$ vibration of the oxime group(s) in the IR spectra of $\mathbf{1}, \mathbf{2 , 3} \mathbf{4}$ and $\mathbf{5 a}$ appear as medium to weak bands at 1640, $1624,1638,1594$ (overlapping with an aromatic stretch) and $1654 \mathrm{~cm}^{-1}$, respectively [38]; the corresponding Raman vibrations are assigned [14,48] to the peaks at $1632(\mathbf{1}), 1624$ (2), 1622 (3) and $1589(4) \mathrm{cm}^{-1}$. The wavenumbers for 2 and 3 are approximately the same with those of the free ligands $3 \mathrm{paoH}$ and $4 \mathrm{paoH}$, respectively. This is strong evidence that the oxime nitrogen does not participate in coordination to $\mathrm{Cd}(\mathrm{II})$, a fact that has been confirmed through single-crystal X-ray crystallography (vide infra). The $v(\mathrm{C}=\mathrm{N})$ band/peak (IR at $1594 \mathrm{~cm}^{-1}$ and Raman at $1638 \mathrm{~cm}^{-1}$ ) for 4 is located at lower wavenumbers compared with those of free dapdoH $\mathrm{H}_{2}$, suggesting oxime-N coordination. Somewhat to our surprise, the $1626 \mathrm{~cm}^{-1}$ band of $2 \mathrm{paoH}$ is shifted to a higher wavenumber in the IR spectrum of $\mathbf{1}\left(1640 \mathrm{~cm}^{-1}\right)$ for which the oxime-N coordination has been confirmed (vide infra). This fact, which is not unusual [14], has been interpreted [50] on the basis that some ligands containing a $\mathrm{C}=\mathrm{N}$ bond (with the carbon atom attached to an aromatic ring) have been shown to undergo a change in the s character of the $\mathrm{N}$ lone pair upon coordination; the $\mathrm{s}$ character of the $\mathrm{N}$ orbital in the $\mathrm{C}=\mathrm{N}$ bond increases resulting in a greater $\mathrm{C}=\mathrm{N}$ stretching force constant relative to the free neutral ligands, and this in turn shifts the $v(\mathrm{C}=\mathrm{N})$ band in the spectra of the complexes to higher frequencies. An analogous trend is observed in the IR spectrum of $\mathbf{5} \mathbf{a}$ for which coordination of both oxime $\mathrm{N}$ atoms is proposed. The medium-intensity IR band at $942 \mathrm{~cm}^{-1}$ for free $2 \mathrm{paoH}$ is assigned to the $v(\mathrm{NO})_{\text {oxime }}$ mode; the corresponding weak Raman peak appears at $950 \mathrm{~cm}^{-1}$ [49]. The $942 \mathrm{~cm}^{-1}$ band is shifted to a lower wavenumber $\left(932 \mathrm{~cm}^{-1}\right)$ in $\mathbf{1}$; this shift is due $[14,39]$ to the coordination of the neutral oxime nitrogen. The same trend is observed in the Raman spectrum of the complex where this mode is located at $925 \mathrm{~cm}^{-1}$. The assignment of the $v(\mathrm{NO})_{\text {oxime }}$ mode for $3 \mathrm{paoH}, 4 \mathrm{paoH}$, dapdoH $\mathrm{H}_{2}$ and $\mathrm{LH}_{4}$ is not an easy task and any discussion about coordination (or non-coordination) shifts in the spectra of the complexes would be risky. 


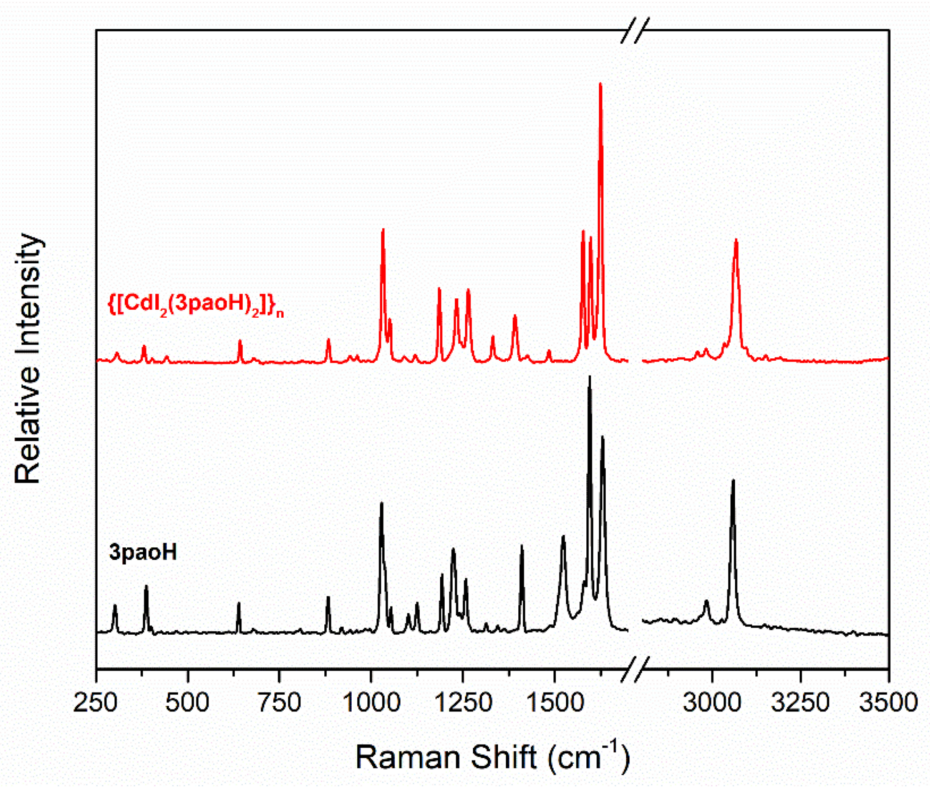

Figure 4. The FT-Raman spectrum of the ligand $3 \mathrm{paoH}$ (black line) and the $\left\{\left[\mathrm{CdI}_{2}(3 \mathrm{paoH})_{2}\right]\right\}_{\mathrm{n}}$ (2) complex (red line).

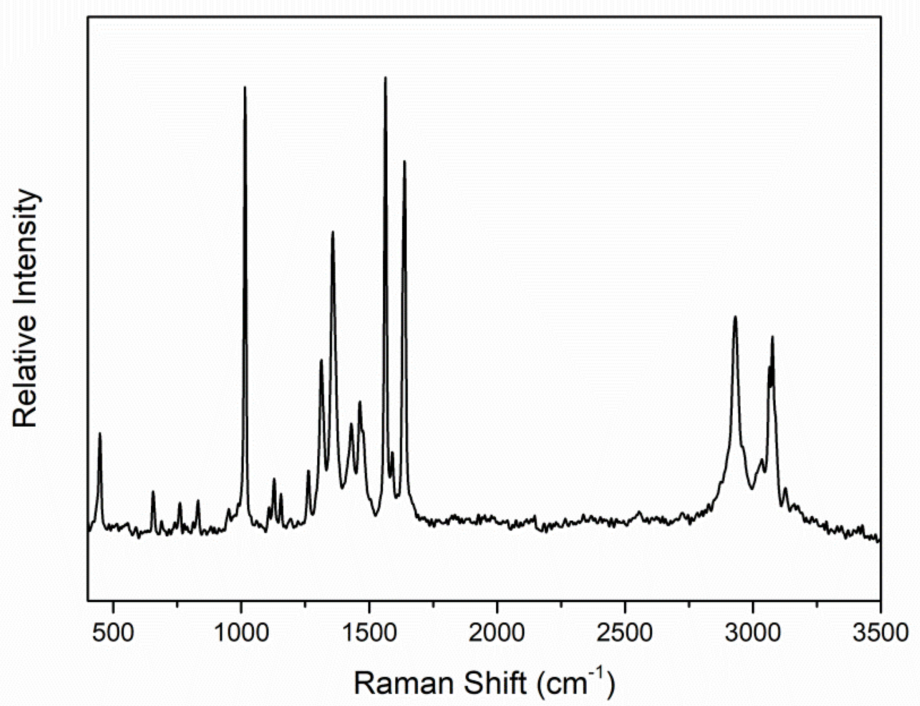

Figure 5. The FT-Raman spectrum of a well-dried (i.e., without lattice EtOH) sample of $\left[\mathrm{CdI}_{2}\left(\right.\right.$ dapdoH $\left.\left._{2}\right)\right](4)$.

The complexes were characterized in solution by ${ }^{1} \mathrm{H}$ NMR spectroscopy in $\mathrm{d}_{6}$-DMSO (Figure S6, Figure S7 and Figure S8). The spectrum of free 2paoH displays singlet signals at $\delta 11.66$ and $8.08 \mathrm{ppm}$ assigned to the hydroxyl proton and to the proton attached to the oxime carbon, respectively, and a doublet signal at $\delta 8.57 \mathrm{ppm}$ assigned to the $\alpha$ aromatic proton (i.e., the proton bonded to the carbon next to the pyridyl nitrogen atom). The corresponding signals in the spectrum of 1 appear at $\delta 10.97,7.42$ and $9.13 \mathrm{ppm}$. The upfield shift of the oxime carbon-bonded proton and the downfield shift of the $\alpha$ proton in the spectrum of the complex both indicate coordination of the two $2 \mathrm{paoH} \mathrm{N}$ atoms in solution [51], suggesting that the structure of $\mathbf{1}$ is retained in solution. This is corroborated by the almost zero value of the molar conductivity of the complex in DMSO $\left(\Lambda_{\mathrm{M}}=4 \mathrm{~S} \mathrm{~cm}^{2} \mathrm{~mol}^{-1}\right.$ for a $10^{-3} \mathrm{M}$ solution at $\left.25^{\circ} \mathrm{C}\right)$ [52]. Given the stability of $\mathbf{1}$ in DMSO, we were rather surprised to realize that 4 (which possesses two chelating rings per ligand dapdoH${ }_{2}$ ) decomposes in solution! Its ${ }^{1} \mathrm{H}$ NMR spectrum in $\mathrm{d}_{6}$-DMSO is identical to that 
of free dapdoH $\mathrm{H}_{2}$ displaying a simple set of signals at $\delta 11.51(-\mathrm{OH}$, singlet), 7.80 (aromatic protons, multiplet) and $2.25\left(-\mathrm{CH}_{3}\right.$, singlet) $\mathrm{ppm}$ in the expected 2:3:6 integration ratio. This result, together with the negligible $\Lambda_{\mathrm{M}}$ value in DMSO, indicates a decomposition probably through Equation (1), where $\mathrm{x} \geq 4$. The $\mathrm{Cd}^{\mathrm{II}}$-I bond is very stable as suggested by the absence of crystal structures of $\mathrm{Cd}(\mathrm{II})$-DMSO complexes possessing ionic iodides [53]. A rather poor-quality (due to solubility reasons) ${ }^{1} \mathrm{H}$ NMR spectrum of 4 in $\mathrm{CDCl}_{3}$ is complicated indicating two different solution species, both of which seem to contain coordinated dapdoH $\mathrm{H}_{2}$. The spectrum of $\mathbf{2}$ in $\mathrm{d}_{6}-\mathrm{DMSO}$ is identical to that of free $3 \mathrm{paoH}$ displaying signals at $\delta 11.57(-\mathrm{OH}$, singlet), $8.21(-\mathrm{CHNOH})$ and doublets/multiplets at 8.75 , $8.57,8.00,7.45$ (aromatic protons) ppm in the expected 1:1:4 integration ratio. Similarly, the spectrum of 3 in the same solvent shows signals at $\delta 11.82(-\mathrm{OH}$, singlet), $8.18(-\mathrm{CHNOH}$, singlet), and 8.60, 7.55 (aromatic protons) ppm being identical with that of free $4 \mathrm{paoH}$. These data indicate that complexes 2 and $\mathbf{3}$ decompose in solution releasing $3 \mathrm{paoH}$ and $4 \mathrm{paoH}$, respectively. The $\Lambda_{\mathrm{M}}$ values of 2 and 3 in DMSO were very small probably indicating decomposition through Equation (2), $\mathrm{x} \geq 4$ and $\mathrm{a}=2$ or 3 .

$$
\begin{gathered}
{\left[\mathrm{CdI}_{2}\left(\text { dapdoH}_{2}\right)\right]+\mathrm{xDMSO} \stackrel{\mathrm{DMSO}_{\rightarrow}}{\rightarrow}\left[\mathrm{CdI}_{2}(\mathrm{DMSO})_{\mathrm{x}}\right]+\text { dapdoH }_{2}} \\
\left\{\left[\mathrm{CdI}_{2}(\mathrm{apaoH})_{2}\right]\right\}_{\mathrm{n}}+\mathrm{xn} \mathrm{DMSO} \stackrel{\mathrm{DMSO}}{\rightarrow} \mathrm{n}\left[\mathrm{CdI}_{2}(\mathrm{DMSO})_{2}\right]+2 \mathrm{napaoH}
\end{gathered}
$$

\subsection{Description of Structures}

The structures of $1-3,4 \cdot 2 \mathrm{EtOH}$ and 5 were determined by single-crystal X-ray crystallography. Crystallographic data are gathered in Table 1. Structural plots are shown in Figures 6-11 and S9-S12. Selected interatomic distances and angles are listed in Tables 2-6.

\begin{tabular}{|c|c|c|c|c|c|}
\hline Parameter & {$\left[\mathrm{CdI}_{2}(2 \mathrm{paoH})_{2}\right](1)$} & $\left\{\left[\mathrm{CdI}_{2}(3 \mathrm{paoH})_{2}\right]\right\}_{n}$ & $\left\{\left[\mathrm{CdI}_{2}(4 \mathrm{paoH})_{2}\right]\right\}_{\mathrm{n}}$ & $\begin{array}{l}{\left[\mathrm{CdI}_{2}\left(\text { dapdoH }_{2}\right)\right] \cdot 2 \mathrm{EtOH}} \\
\quad(4 \cdot 2 \mathrm{EtOH})\end{array}$ & {$\left[\mathrm{CdI}_{2}\left(\mathrm{~L}^{\prime} \mathbf{H}_{2}\right)\right](5)$} \\
\hline Empirical formula & $\mathrm{C}_{12} \mathrm{H}_{12} \mathrm{CdI}_{2} \mathrm{~N}_{4} \mathrm{O}_{2}$ & $\mathrm{C}_{12} \mathrm{H}_{12} \mathrm{CdI}_{2} \mathrm{~N}_{4} \mathrm{O}_{2}$ & $\mathrm{C}_{12} \mathrm{H}_{12} \mathrm{CdI}_{2} \mathrm{~N}_{4} \mathrm{O}_{2}$ & $\mathrm{C}_{13} \mathrm{H}_{23} \mathrm{CdI}_{2} \mathrm{~N}_{3} \mathrm{O}_{4}$ & $\mathrm{C}_{11} \mathrm{H}_{15} \mathrm{CdI}_{2} \mathrm{~N}_{3} \mathrm{O}_{2}$ \\
\hline Formula weight & 610.46 & 610.46 & 610.46 & 651.54 & 587.46 \\
\hline Crystal system & monoclinic & Monoclinic & monoclinic & triclinic & orthorhombic \\
\hline Space group & $\mathrm{C} 2 / \mathrm{c}$ & $\mathrm{C} 2 / \mathrm{m}$ & $\mathrm{C} 2 / \mathrm{m}$ & $P \overline{1}$ & Pcnb \\
\hline Color & colorless & Colorless & colorless & colorless & colorless \\
\hline Crystal size, $\mathrm{mm}$ & $0.41 \times 0.20 \times 0.17$ & $0.21 \times 0.21 \times 0.06$ & $0.23 \times 0.13 \times 0.05$ & $0.35 \times 0.18 \times 0.13$ & $0.35 \times 0.19 \times 0.08$ \\
\hline$a, \AA$ & $7.9245(2)$ & $25.0595(11)$ & $24.8525(7)$ & 8.0032(19) & $6.4986(3)$ \\
\hline$b, \AA$ & $13.7155(2)$ & $4.1616(2)$ & $4.1618(10)$ & $9.824(2)$ & $15.0095(6)$ \\
\hline$c, \AA$ & $15.6259(2)$ & $7.9660(4)$ & $8.1913(3)$ & 14.215(3) & $17.7360(7)$ \\
\hline$\alpha_{,}^{\circ}$ & 90.0 & 90.0 & 90.0 & $81.439(6)$ & 90.0 \\
\hline$\beta,{ }^{\circ}$ & 101.35(1) & $98.413(1)$ & $98.223(1)$ & $78.146(5)$ & 90.0 \\
\hline$\gamma,{ }^{\circ}$ & 90.0 & 90.0 & 90.0 & $74.771(6)$ & 90.0 \\
\hline Volume, $\AA^{3}$ & $1665.13(8)$ & $821.82(7)$ & $838.52(4)$ & $1050.0(4)$ & $1729.98(13)$ \\
\hline $\mathrm{Z}$ & 4 & 2 & 2 & 2 & 4 \\
\hline Temperature, $\mathrm{K}$ & 160 & 170 & 160 & 160 & 160 \\
\hline Radiation, $\AA / 2 \theta_{\max }$ & $\begin{array}{c}\mathrm{Cu} \mathrm{K} \alpha \\
(1.54178) / 130.0\end{array}$ & $\begin{array}{c}\mathrm{Cu} \mathrm{K} \alpha \\
(1.54178) / 129.8\end{array}$ & $\begin{array}{c}\text { Mo K } \alpha \\
(0.71073) / 54.0\end{array}$ & Mo K $\alpha(0.71073) / 54.0$ & $\begin{array}{c}\text { Mo K } \alpha \\
(0.71073) / 54.0\end{array}$ \\
\hline Calculated density, $\mathrm{g} \cdot \mathrm{cm}^{-3}$ & 2.435 & 2.467 & 2.418 & 2.061 & 2.256 \\
\hline Absorption coefficient, $\mathrm{mm}^{-1}$ & 39.71 & 40.23 & 4.99 & 4.00 & 4.83 \\
\hline $\begin{array}{c}\text { Number of measured, } \\
\text { independent, and observed }[I> \\
2 \sigma(I)] \text { reflections }\end{array}$ & $10,738,1385,1333$ & $5658,718,661$ & $10,187,1042,988$ & $32,407,4564,4189$ & $35,910,1875,1753$ \\
\hline Number of parameters & 98 & 65 & 65 & 216 & 89 \\
\hline Final $R$ indices $[I>2 \sigma(I)]^{\mathrm{a}}$ & $\begin{array}{r}R_{1}=0.0384 \\
w_{R 2}=0.0902\end{array}$ & $\begin{array}{r}R_{1}=0.0499 \\
w_{R 2}=0.1079\end{array}$ & $\begin{array}{r}R_{1}=0.0166 \\
w_{R 2}=0.0398\end{array}$ & $\begin{array}{l}R_{1}=0.0224 \\
w_{R 2}=0.0570\end{array}$ & $\begin{array}{l}R_{1}=0.0337 \\
w_{R 2}=0.0707\end{array}$ \\
\hline Goodness-of-fit on $F^{2}$ & 1.06 & 1.10 & 1.05 & 1.02 & 1.11 \\
\hline $\begin{array}{l}\text { Largest differences peak and } \\
\text { hole }\left(\mathrm{e} \AA^{-3}\right)\end{array}$ & $1.28 /-1.66$ & $1.22 /-1.20$ & $0.66 /-0.52$ & $0.53 /-0.74$ & $0.50 /-0.84$ \\
\hline
\end{tabular}

Table 1. Crystallographic data and refinement parameters for the structures of $1,2,3,4 \cdot 2 \mathrm{EtOH}$ and 5.

$\left.{ }^{\mathrm{a}} R_{1}=\Sigma\left(\left|F_{\mathrm{o}}\right|-\left|F_{\mathrm{c}}\right|\right) / \Sigma\left(\left|F_{\mathrm{o}}\right|\right), w R_{2}=\left\{\Sigma\left[w\left(F_{\mathrm{o}}{ }^{2}-F_{\mathrm{c}}{ }^{2}\right)^{2}\right] / \Sigma\left[w\left(F_{\mathrm{o}}{ }^{2}\right)^{2}\right]\right\}^{1 / 2}, w=14 \sigma^{2}\left(F_{\mathrm{o}}{ }^{2}\right)+(\alpha P)^{2}+b P\right]$, where $P=\left[\max \left(F_{\mathrm{o}}{ }^{2}, 0\right)+2 F_{\mathrm{c}}{ }^{2}\right] / 3$. $(\alpha=0.0029$ and $b=7.5036$ for $1 ; \alpha=0.0519$ and $b=2.3524$ for $2 ; \alpha=0.0232$ and $b=0.8669$ for $3 ; \alpha=0.0281$ and $b=1.0643$ for $4 \cdot 2 \mathrm{EtOH} ; \alpha=0.0151, b=7.8149$ for 5 ). 


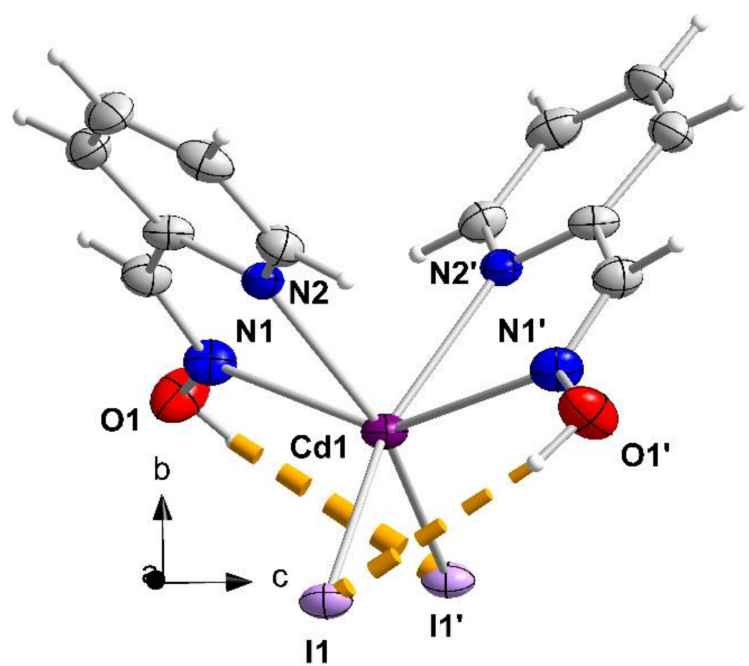

Figure 6. The structure of the $\left[\mathrm{CdI}_{2}(2 \mathrm{paoH})_{2}\right]$ molecule that is present in $\mathbf{1}$. The thermal ellipsoids are presented at the $50 \%$ probability level. Only the metal, the donor atoms and the oxime oxygen atoms are numbered. The dashed lines indicate intramolecular hydrogen bonds. Symmetry operation: $\left({ }^{\prime}\right)=x, y,-z+1 / 2$.

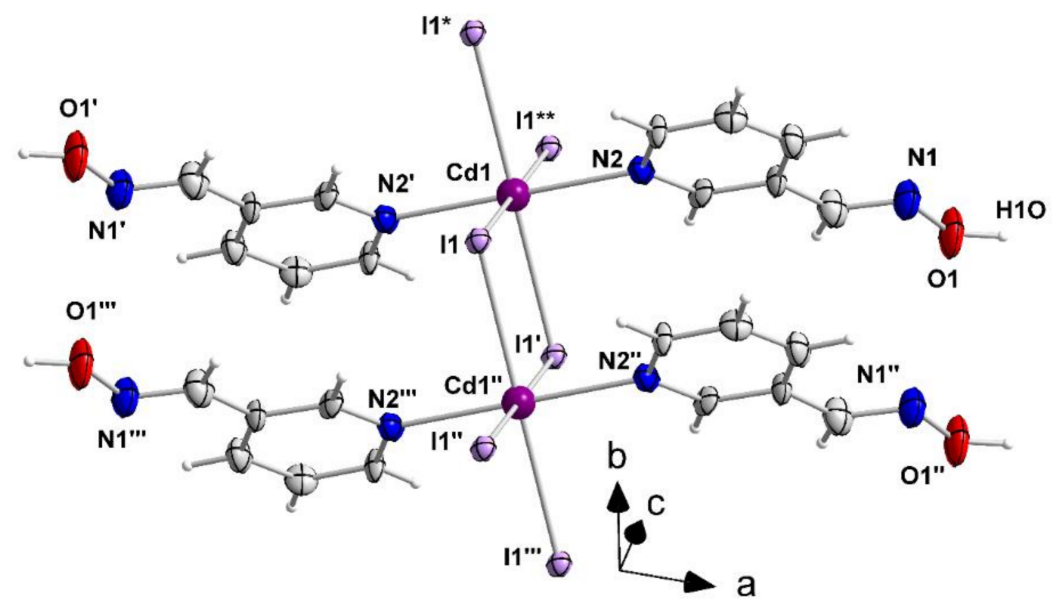

Figure 7. A small portion of the 1D chain that is present in the crystal structure of $\left\{\left[\mathrm{CdI}_{2}(3 \mathrm{paoH})_{2}\right]\right\}_{\mathrm{n}}(2)$. The thermal ellipsoids are presented at the $50 \%$ probability level. Only the $\mathrm{Cd}^{\mathrm{II}}$ atoms, the donor atoms and the $\mathrm{N}, \mathrm{O}$ atoms of the oxime groups are numbered. Symmetry operations: $\left({ }^{\prime}\right)=-x, y,-z ;\left(^{\prime \prime}\right)=x, y-1, z ;\left(^{\prime \prime \prime}\right)=-x, y-1,-z ;\left(^{*}\right)=x, y+1, z ;\left(^{* *}\right)=-x, y+1,-z$.

Complex $\left[\mathrm{CdI}_{2}(2 \mathrm{paoH})_{2}\right](1)$ crystallizes in the monoclinic space group $\mathrm{C} 2 / c$. As the complex possesses a 2-fold axis of symmetry passing through $\mathrm{Cd} 1$ and bisecting the I1-Cd1-I1' angle (Wyckoff position 4e: $\mathrm{O}, y, 1 / 4)$, there is $1 / 2\left[\mathrm{CdI}_{2}(2 \mathrm{paoH})_{2}\right]$ molecule in the asymmetric unit of the cell. The $\mathrm{Cd}^{\mathrm{II}}$ center forms coordination bonds with two terminal iodo (or iodido) groups (I1, I1 '), two oxime nitrogen atoms (N1, N1 ') and two 2-pyridyl nitrogen atoms (N2, N2 '); the four nitrogen atoms belong to two 1.011 (Harris notation [54]) $2 \mathrm{paoH}$ ligands. The coordination polyhedron of the metal ion is a very distorted octahedron, the cis and trans donor atom-metal ion-donor atom bond angles being in the ranges $66.9(2)-114.8(1)$ and $145.8(2)-153.6(1)^{\circ}$, respectively. The distorted geometry arises from the small bite angles of the two 5-membered N(oxime)CCN(2-pyridyl)Cd1 rings; these two angles (equal by symmetry) are 66.9(2) ${ }^{\circ}$, much smaller than the ideal value of $90^{\circ}$. The octahedral molecule is the cis-cis-trans isomer considering the octahedral positions of the iodo groups, the 2-pyridyl and the oxime nitrogen atoms, respectively. The Cd ${ }^{\mathrm{II}}$ 
$\mathrm{N}\left(2\right.$-pyridyl) bond length [2.402(5) $\AA$ ] is smaller than the $\mathrm{Cd}^{\mathrm{II}}$-N(oxime) one [2.457(6) $\AA$ ] There are two intramolecular hydrogen bonds with the uncoordinated oxime oxygen atoms $\left(\mathrm{O} 1, \mathrm{O} 1^{\prime}\right)$ as donors and the coordinated iodo groups (I1, I1 ') as acceptors, namely $\mathrm{O} 1-\mathrm{H}(\mathrm{O} 1) \cdots \mathrm{I} 1^{\prime}$ [and $\mathrm{O}^{\prime}{ }^{\prime}-\mathrm{H}\left(\mathrm{O} 1{ }^{\prime}\right) \cdots \mathrm{I} 1$ ]. Their parameters are: $\mathrm{O} 1 \cdots \mathrm{I} 1{ }^{\prime}=3.605(5) \AA$, $\mathrm{H}(\mathrm{O} 1)^{\cdots} \mathrm{I} 1^{\prime}=2.90 \AA$ and $\mathrm{O} 1-\mathrm{H}(\mathrm{O} 1)^{\cdots} \mathrm{I}^{\prime}{ }^{\prime}=142.0^{\circ}$.

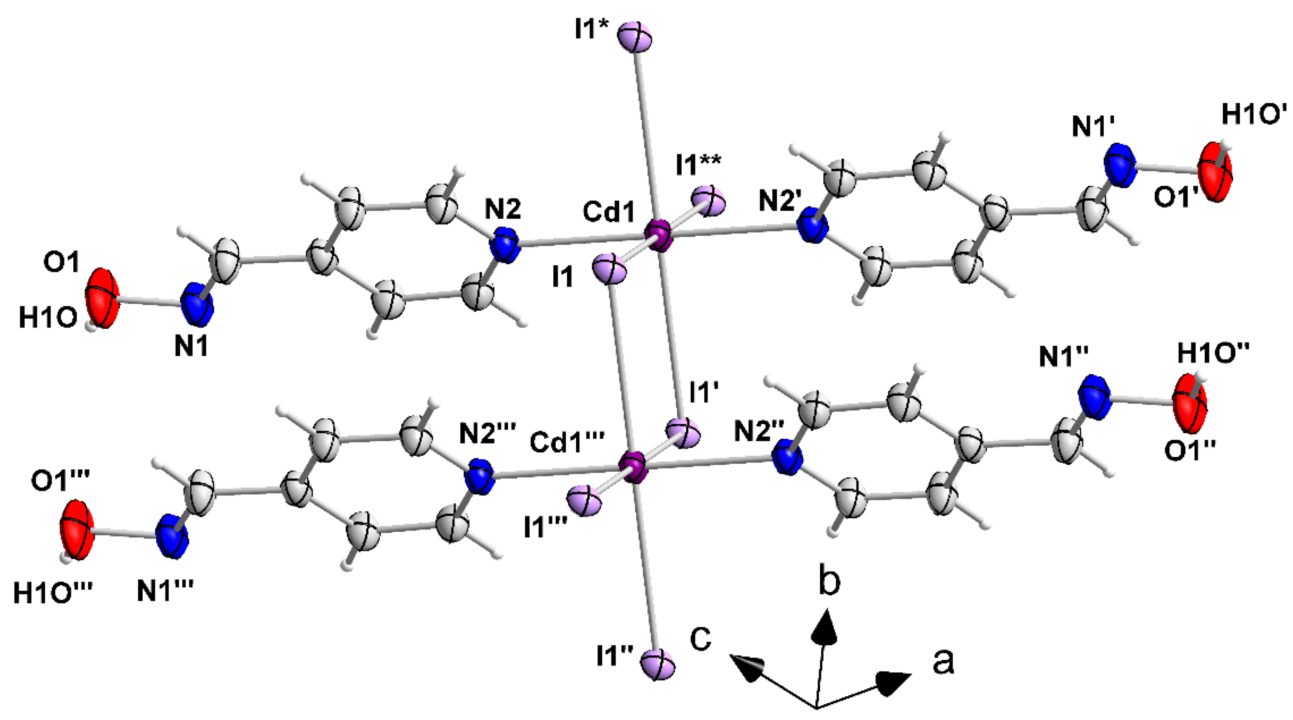

Figure 8. A small portion of the $1 \mathrm{D}$ chain that is present in the crystal structure of $\left\{\left[\mathrm{CdI}_{2}(4 \mathrm{paoH})_{2}\right]\right\}_{\mathrm{n}}(3)$. The thermal ellipsoids are presented at the $50 \%$ probability level. Only the $\mathrm{Cd}^{\mathrm{II}}$ atoms, the donor atoms and the $\mathrm{N}, \mathrm{O}$ atoms of the oxime groups are numbered. Symmetry operations: $\left({ }^{\prime}\right)=-x, y,-z ;\left(^{\prime \prime}\right)=-x, y-1,-z ;\left(^{\prime \prime \prime}\right)=x, y-1, z ;\left(^{*}\right)=x, y+1, z ;\left(^{* *}\right)=-x, y+1,-z$.

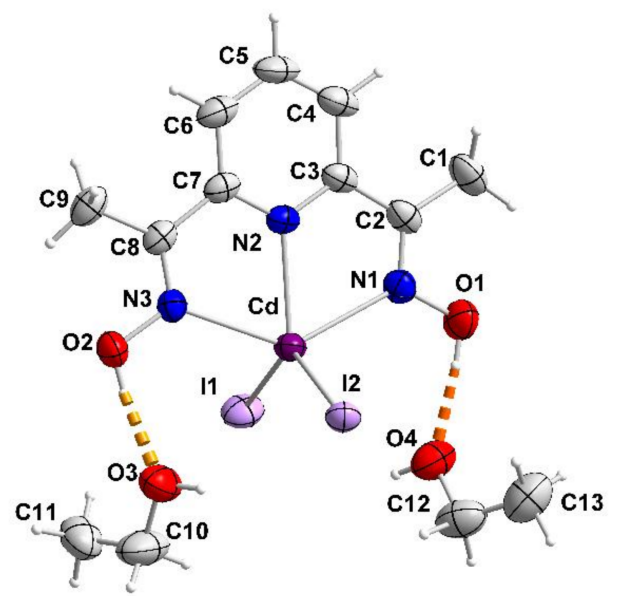

Figure 9. The molecules $\left[\mathrm{CdI}_{2}\left(\mathrm{dapdoH}_{2}\right)\right]$ and $\mathrm{EtOH}$ that are present in the crystal structure of $4 \cdot 2 \mathrm{EtOH}$. The thermal ellipsoids are presented at the $50 \%$ probability level. The thick dashed orange lines indicate hydrogen bonds between the oxime groups and the lattice $\mathrm{EtOH}$ molecules.

Neighboring molecules of 1 interact through $\pi-\pi$ stacking interactions involving the 2-pyridyl rings (symmetry operation: $-x-1 / 2,-y+1 / 2,-z$ ) forming chains parallel to the [101] crystallographic direction (Figure S9), which are further connected through weak hydrogen bonding interactions creating the 3D architecture of the crystal structure. The distance between the neighboring centrosymmetric 2-pyridyl rings within the chain is 3.83(1) A. 


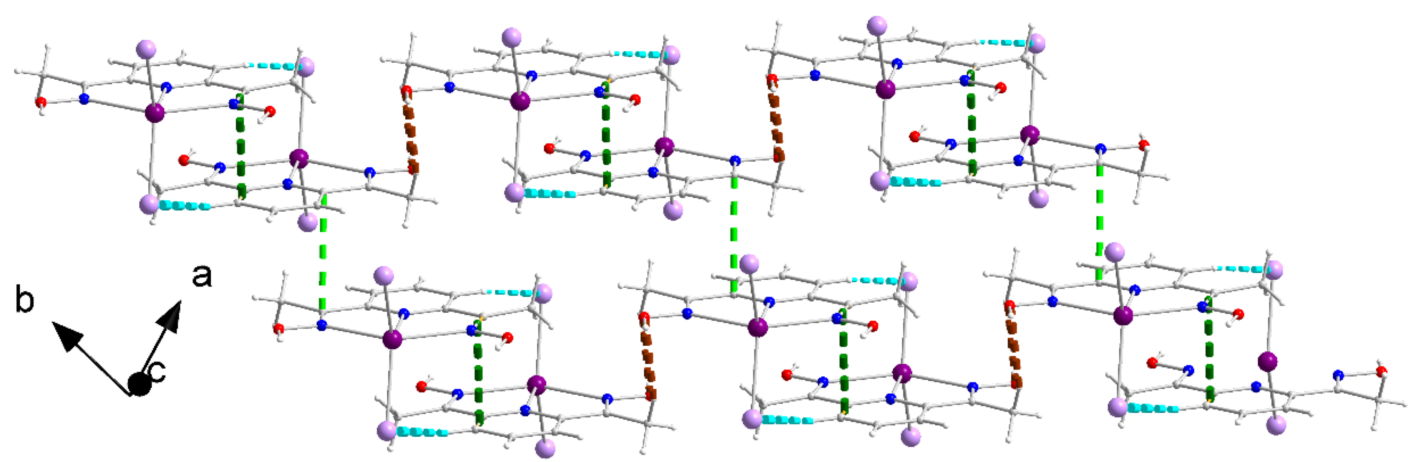

Figure 10. Layers of molecules $\left[\mathrm{CdI}_{2}\left(\mathrm{dapdoH}_{2}\right)\right]$ parallel to the (001) plane in the crystal structure of $4 \cdot 2 \mathrm{EtOH}$. The thick dashed dark and light green lines represent $\pi-\pi$ interactions. The thick dashed cyan and brown lines represent the $\mathrm{C} 4-\mathrm{H}(\mathrm{C} 4)-\mathrm{I} 2$ and $\mathrm{C} 9-\mathrm{H}_{\mathrm{C}}(\mathrm{C} 9) \cdots \mathrm{O} 2$ hydrogen bonds, respectively. The hydrogen bonds involving the lattice $\mathrm{EtOH}$ molecules have not been drawn for clarity reasons; for more details see the above text and Table S1.

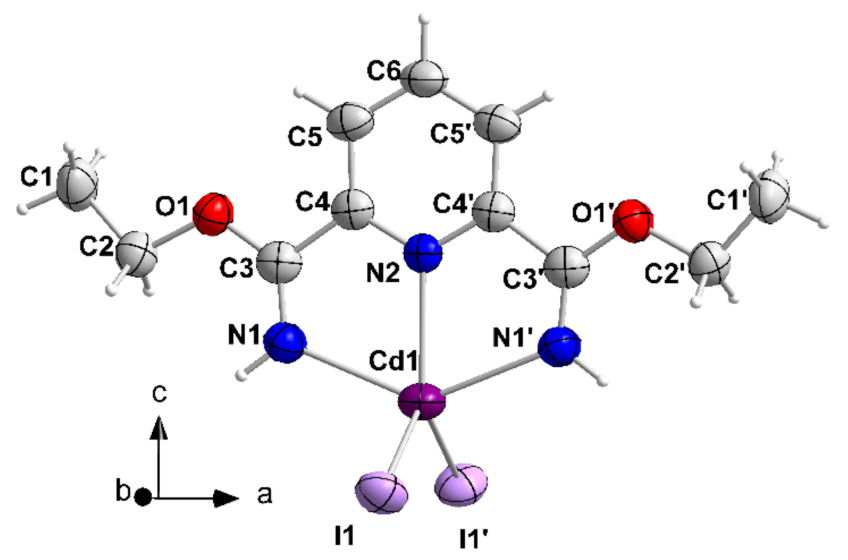

Figure 11. The structure of $\left[\mathrm{CdI}_{2}\left(\mathrm{~L}^{\prime} \mathrm{H}_{2}\right)\right]$ molecule that is present in 5 . The thermal ellipsoids are presented at the $50 \%$ probability level. Symmetry operation: $\left(^{\prime}\right)=-x,-y+3 / 2, z$.

Table 2. Selected bond lengths $(\AA)$ and angles $\left({ }^{\circ}\right)$ for the complex $\left[\mathrm{CdI}_{2}(2 \mathrm{paoH})_{2}\right](\mathbf{1})^{\mathrm{a}}$.

\begin{tabular}{|c|c|c|c|}
\hline \multicolumn{2}{|c|}{ Bond Lengths (Å) } & \multicolumn{2}{|c|}{ Bond Angles $\left({ }^{\circ}\right)$} \\
\hline Cd1-I1 & $2.829(1)$ & I1-Cd1-I1' & $103.4(1)$ \\
\hline Cd1-N1 & $2.457(6)$ & I1-Cd1-N1 & $114.8(1)$ \\
\hline Cd1-N2 & $2.402(5)$ & I1-Cd1-N1' & $86.8(1)$ \\
\hline C1-N1 & $1.253(8)$ & I1-Cd1-N2 & $89.8(1)$ \\
\hline \multirow[t]{5}{*}{ N1-O1 } & $1.398(7)$ & I1-Cd1-N2' & 153.6(1) \\
\hline & & N1-Cd1-N1' & $145.8(2)$ \\
\hline & & N1-Cd1-N2 & $66.9(2)$ \\
\hline & & N1-Cd1-N2' & $88.2(2)$ \\
\hline & & N2-Cd1-N2' & $87.8(2)$ \\
\hline
\end{tabular}

a Symmetry code: $\left({ }^{\prime}\right)=-x, y,-z+1 / 2$. Atoms $\mathrm{C} 1$ and $\mathrm{C}^{\prime}$, not labelled in Figure 6 , are the oxime carbon atoms of coordinated $2 \mathrm{paoH}$. 
Table 3. Selected interatomic distances $(\AA)$ and angles $\left(^{\circ}\right)$ for the polymeric compound $\left\{\left[\mathrm{CdI}_{2}(3 \mathrm{paoH})_{2}\right]\right\}_{\mathrm{n}}(2){ }^{\mathrm{a}}$.

\begin{tabular}{|c|c|c|c|}
\hline \multicolumn{2}{|c|}{ Interatomic Distances (̊̊) } & \multicolumn{2}{|l|}{ Interatomic Angles $\left({ }^{\circ}\right)$} \\
\hline $\mathrm{Cd} 1-\mathrm{N} 2 / \mathrm{N} 2{ }^{\prime}$ & $2.353(9)$ & $\mathrm{N} 2-\mathrm{Cd} 1-\mathrm{N} 2{ }^{\prime}=\mathrm{I} 1-\mathrm{Cd} 1-\mathrm{I} 1^{\prime \prime}=\mathrm{I} 1^{\prime}-\mathrm{Cd} 1-\mathrm{I} 1{ }^{*}$ & $180.0(1)$ \\
\hline $\mathrm{Cd} 1-\mathrm{I} 1 / \mathrm{I} 1{ }^{\prime \prime}$ & 2.986(1) & $\mathrm{I} 1-\mathrm{Cd} 1-\mathrm{I} 1^{\prime}=\mathrm{I} 1^{*}$-Cd1-I1 ** & $91.6(1)$ \\
\hline $\mathrm{Cd} 1 \cdots \mathrm{Cd} 1^{\prime \prime}$ & $4.162(1)$ & $\mathrm{I} 1-\mathrm{Cd} 1-\mathrm{I} 1{ }^{*}=\mathrm{I} 1^{\prime}-\mathrm{Cd} 1-\mathrm{I} 1 * *$ & $88.4(2)$ \\
\hline \multirow[t]{3}{*}{$\begin{array}{c}\mathrm{N} 1-\mathrm{O} 1=\mathrm{N} 1{ }^{\prime}-\mathrm{O} 1{ }^{\prime} \\
=\mathrm{N} 1{ }^{\prime \prime}-\mathrm{O} 1^{\prime \prime}=\mathrm{N} 1^{\prime \prime \prime}-\mathrm{O} 1^{\prime \prime \prime}\end{array}$} & $1.423(14)$ & $\begin{array}{c}\mathrm{I}^{\prime}-\mathrm{Cd} 1-\mathrm{N} 2=\mathrm{I} 1-\mathrm{Cd} 1-\mathrm{N} 2^{\prime}=\mathrm{I} 1^{*}-\mathrm{Cd} 1-\mathrm{N} 2{ }^{\prime} \\
=\mathrm{I} 1{ }^{* *}-\mathrm{Cd} 1-\mathrm{N} 2\end{array}$ & $90.9(2)$ \\
\hline & & $\begin{aligned} \mathrm{I} 1-\mathrm{Cd} 1-\mathrm{N} 2 & =\mathrm{I} 1^{\prime}-\mathrm{Cd} 1-\mathrm{N} 2{ }^{\prime}=\mathrm{I} 1{ }^{*}-\mathrm{Cd} 1-\mathrm{N} 2 \\
& =\mathrm{I} 1^{\prime \prime}-\mathrm{Cd} 1-\mathrm{N} 2{ }^{\prime}\end{aligned}$ & $89.1(2)$ \\
\hline & & Cd1-I1-Cd1" & $88.4(2)$ \\
\hline
\end{tabular}

Table 4. Selected interatomic distances $(\AA)$ and angles $\left(^{\circ}\right)$ for the polymeric compound $\left\{\left[\mathrm{CdI}_{2}(4 \mathrm{paoH})_{2}\right]\right\}_{\mathrm{n}}(3)^{\mathrm{a}}$

\begin{tabular}{|c|c|c|c|}
\hline \multicolumn{2}{|c|}{ Interatomic Distances ( $\mathrm{A})$} & \multicolumn{2}{|l|}{ Interatomic Angles $\left({ }^{\circ}\right)$} \\
\hline $\mathrm{Cd} 1-\mathrm{N} 2 / \mathrm{N} 2{ }^{\prime}$ & $2.353(2)$ & $\mathrm{N} 2-\mathrm{Cd} 1-\mathrm{N} 2{ }^{\prime}=\mathrm{I} 1-\mathrm{Cd} 1-\mathrm{I} 1{ }^{\prime \prime}=\mathrm{I} 1^{\prime}-\mathrm{Cd} 1-\mathrm{I} 1 *$ & $180.0(1)$ \\
\hline $\mathrm{Cd} 1-\mathrm{I} 1 / \mathrm{I} 11^{\prime} / \mathrm{I} 1$ */I1 ** & 2.991(1) & $\mathrm{I} 1-\mathrm{Cd} 1-\mathrm{I} 1^{\prime}=\mathrm{I} 11^{*}-\mathrm{Cd} 1-\mathrm{I} 1^{\prime \prime}$ & $91.8(1)$ \\
\hline $\mathrm{Cd} 1 \cdots \mathrm{Cd} 1^{\prime \prime \prime}$ & $4.162(1)$ & $\mathrm{I} 1-\mathrm{Cd} 1-\mathrm{I} 1{ }^{*}=\mathrm{I} 1^{\prime}-\mathrm{Cd} 1-\mathrm{I} 1^{\prime \prime}$ & $88.2(1)$ \\
\hline \multirow[t]{3}{*}{$\mathrm{N} 1-\mathrm{O} 1=\mathrm{N} 1{ }^{\prime}-\mathrm{O} 1{ }^{\prime}$} & $1.403(4)$ & $\mathrm{I} 1-\mathrm{Cd} 1-\mathrm{N} 2{ }^{\prime}=\mathrm{I} 1^{\prime}-\mathrm{Cd} 1-\mathrm{N} 2=\mathrm{I} 1{ }^{*}-\mathrm{Cd} 1-\mathrm{N} 2{ }^{\prime}=\mathrm{I} 1{ }^{* *}-\mathrm{Cd} 1-\mathrm{N} 2$ & $90.7(1)$ \\
\hline & & $\mathrm{I} 1-\mathrm{Cd} 1-\mathrm{N} 2=\mathrm{I} 1^{\prime}-\mathrm{Cd} 1-\mathrm{N} 2{ }^{\prime}=\mathrm{I} 1{ }^{*}-\mathrm{Cd} 1-\mathrm{N} 2=\mathrm{I} 1{ }^{* *}-\mathrm{Cd} 1-\mathrm{N} 2{ }^{\prime}$ & $89.3(1)$ \\
\hline & & $\mathrm{Cd} 1-\mathrm{I} 1-\mathrm{Cd} 1^{\prime \prime \prime}$ & $88.2(1)$ \\
\hline
\end{tabular}

Table 5. Selected bond lengths $(\AA)$ and angles $\left({ }^{\circ}\right)$ for complex $\left[\mathrm{CdI}_{2}\left(\mathrm{dapdoH}_{2}\right)\right] \cdot 2 \mathrm{EtOH}(4 \cdot 2 \mathrm{EtOH})$.

\begin{tabular}{cccc}
\hline \multicolumn{2}{c}{ Bond Lengths $(\AA)$} & \multicolumn{2}{c}{ Bond Angles $\left.\mathbf{(}^{\circ}\right)$} \\
\hline Cd-I1 & $2.722(1)$ & I1-Cd-I2 & $126.7(1)$ \\
Cd-I2 & $2.733(1)$ & I1-Cd-N1 & $100.2(1)$ \\
Cd-N1 & $2.421(2)$ & I1-Cd-N2 & $117.8(1)$ \\
Cd-N2 & $2.333(2)$ & I1-Cd-N3 & $98.8(1)$ \\
Cd-N3 & $2.443(2)$ & I2-Cd-N1 & $101.0(1)$ \\
C2-N1 & $1.279(4)$ & I2-Cd-N2 & $115.4(1)$ \\
N1-O1 & $1.380(3)$ & I2-Cd-N3 & $99.6(1)$ \\
C8-N3 & $1.275(3)$ & N1-Cd-N2 & $67.5(1)$ \\
N3-O2 & $1.384(3)$ & N1-Cd-N3 & $134.9(1)$ \\
& & N2-Cd-N3 & $67.5(1)$ \\
\hline
\end{tabular}

Table 6. Selected bond lengths $(\AA)$ and angles $\left(^{\circ}\right)$ for complex $\left[\mathrm{CdI}_{2}\left(\mathrm{~L}^{\prime} \mathrm{H}_{2}\right)\right](5)^{\mathrm{a}}$.

\begin{tabular}{|c|c|c|c|}
\hline \multicolumn{2}{|c|}{ Bond Lengths (Å) } & \multicolumn{2}{|c|}{ Bond Angles $\left({ }^{\circ}\right)$} \\
\hline Cd1-I1 & $2.738(1)$ & I1-Cd1-I1' & $119.4(1)$ \\
\hline Cd1-N1 & $2.423(4)$ & I1-Cd1-N1 & $100.7(1)$ \\
\hline Cd1-N2 & $2.344(5)$ & I1-Cd1-N2 & $120.3(1)$ \\
\hline C3-N1 & $1.268(6)$ & I1-Cd1-N1' & $100.9(1)$ \\
\hline C3-O1 & $1.335(6)$ & N1-Cd1-N2 & $68.2(1)$ \\
\hline $\mathrm{O} 1-\mathrm{C} 2$ & $1.451(6)$ & N1-Cd1-N1' & $136.4(1)$ \\
\hline C1-C2 & $1.489(7)$ & & \\
\hline
\end{tabular}

a Symmetry code: $\left({ }^{\prime}\right)=-x,-y+3 / 2, z$.

Compound 2 consists of linear 1D chains. It crystallizes in the monoclinic space group $\mathrm{C} 2 / \mathrm{m}$ and the asymmetric unit contains $\frac{1}{4}$ of the repeating unit $\left[\mathrm{CdI}_{2}(3 \mathrm{paoH})_{2}\right]$. The $\mathrm{Cd} 1$ centers sit on Wyckoff positions $2 \mathrm{a}(0,0.0,0)$ with $2 / m$ point group symmetry, with the 2-fold axis being parallel to the $b$ axis and the mirror plane cutting it at the $y=0.0$ point. The atoms of the organic ligand are located on a mirror plane as all occupy the $4 \mathrm{i}(x, 0.0, z)$ Wyckoff positions with point group symmetry $m$. The I1 atoms are also located on 4i-type sites $(x, 0, y)$ with a point group symmetry $m$, but in this case the mirror plane crosses the $b$ axis at the $y=0.5$ point. The $\mathrm{Cd}^{\mathrm{II}}$ and I atoms form chains parallel to the $b$ axis and the 
3paoH ligands are bonded to the metal ions in directions normal to the chain axis. Thus, the $\mathrm{Cd}^{\mathrm{II}}$ atoms are doubly bridged by two symmetric $\mu$-iodo groups and two monodentate 1.0103 paoH ligands complete a slightly distorted octahedral coordination at each metal. The donor atom of 3paoH is the pyridyl nitrogen. The Cd-I bond lengths in 2 [2.986(1) A] are larger than in 1 [2.829(1) $\AA$ ] due to the bridging character of the iodo ligands in the former as compared to their terminal character in the latter. The $\mathrm{Cd}^{\mathrm{II}} \cdots \mathrm{Cd}^{\mathrm{II}}$ distance is 4.162(1) $\AA$. Neighboring chains in the crystal interact through intermolecular O1-H(O1) ${ }^{\cdots}$ I1 hydrogen bonds and form layers parallel to the (110) plane (Figure S10). The metric parameters of the crystallographically unique hydrogen bond $\mathrm{O} 1-\mathrm{H}(\mathrm{O} 1) \cdots \mathrm{I} 1(x+1 / 2, y+1 / 2, z)$ are: $\mathrm{O} 1{ }^{\cdots} \mathrm{I} 1=3.528(10) \AA, \mathrm{H}(\mathrm{O} 1)^{\cdots}{ }^{\cdots} \mathrm{I} 1=2.63(3) \AA$ and $\mathrm{O}-\mathrm{H}(\mathrm{O} 1)^{\cdots} \mathrm{I} 1=174(12)^{\circ}$.

The molecular structure and the supramolecular features of 3 are strikingly similar with those of 2 . The Cd1 centers sit on the Wyckoff positions $2 b(0,0.5,0)$ with $2 / m$ point group symmetry; the 2-fold axis is parallel to the $b$ axis and the mirror plane cuts it at the $y=0.5$ point. Again, the atoms of the $1.0104 \mathrm{paoH}$ ligand are located on a mirror plane, as all occupy the $4 \mathrm{i}(x, 0.5, z)$ Wyckoff positions with $m$ point group symmetry. The I1 atoms are also located on 4 i-type sites $(x, 0, y)$ with point group symmetry $m$, but in this case the mirror plane crosses the $b$ axis at the $y=0.0$ point. The $\mathrm{Cd}^{\mathrm{II}} \cdots \mathrm{Cd}^{\mathrm{II}}$ distances are exactly the same [4.162(1) $\AA$ ] in 2 and 3. Similarly to the crystal structure of 2 , neighboring chains of 3 interact through $\mathrm{O}$ (oxime) $-\mathrm{H} \cdots$ I hydrogen bonds forming layers parallel to the (110) plane (Figure S11). The metric parameters are somewhat different compared to those in 2, due to the different positions of the oxime groups in the pyridyl rings; these are O1$\mathrm{H}(\mathrm{O} 1)^{\cdots} \mathrm{I} 1(x-1 / 2, y+1 / 2, z)=3.501(3) \AA, \mathrm{H}(\mathrm{O} 1) \cdots \mathrm{I} 1(x-1 / 2, y+1 / 2, z)=2.81(5) \AA$ and $\mathrm{O} 1-\mathrm{H}(\mathrm{O} 1) \cdots \mathrm{I} 1(x-1 / 2, y+1 / 2, z)=150(4) \AA$.

The crystal structure of $4 \cdot 2 \mathrm{EtOH}$ consists of mononuclear molecules $\left[\mathrm{CdI}_{2}\left(\mathrm{dapdoH}_{2}\right)\right]$ and lattice $\mathrm{EtOH}$ molecules in an 1:2 ratio. The asymmetric unit of the cell contains the full complex molecule and the two solvent molecules. Each of the latter interacts (as acceptor) with one "free" (i.e., uncoordinated) oxime oxygen atom (donor) of the dapdoH $\mathrm{H}_{2}$ ligand (Figure 9, Table S1). The $\mathrm{Cd}^{\mathrm{II}}$ atom forms coordination bonds with two terminal iodo ligands (I1, I2), the two oxime nitrogen atoms (N1, N3) and the pyridyl nitrogen atom (N2) of dapdoH $\mathrm{H}_{2}$. Thus, the organic molecule behaves as a 1.00111 ligand and participates in two 5-membered chelating rings with the metal ion. The $\mathrm{Cd}^{\mathrm{II}}-\mathrm{N}$ (pyridyl) bond $[2.333(2) \AA]$ is slightly stronger than the $\mathrm{Cd}^{\mathrm{II}}-\mathrm{N}$ (oxime) bonds [2.421(2), 2.443(2) $\AA$ ]. The terminal Cd $\mathrm{Cd}^{\mathrm{II}}$-I bonds [2.722(1), 2.733(1) $\AA$ ] are stronger than the corresponding bonds in $1[2.829(1) \AA]$, and this is due to the lower coordination number of $\mathrm{Cd}^{\mathrm{II}}$ in $4 \cdot 2 \mathrm{EtOH}$ (five) compared with that in 1 (six). The coordination geometry of $\mathrm{Cd}^{\mathrm{II}}$ in the complex is extremely distorted, a fact that is primarily attributed to the small bite angles of the two 5-membered N(oxime)CCN(pyridyl)Cd chelating rings; both $\mathrm{N}$ (oxime)-Cd-N(pyridyl) coordination angles are $67.5(1)^{\circ}$. The geometry can be either described as a very distorted trigonal bipyramidal one with atoms N1 and N3 defining the axial positions, or as a very distorted square pyramidal one with atoms I1, I2, N1, N3 occupying the basal plane and $\mathrm{N} 2$ being at the apical position.

The molecules $\left[\mathrm{CdI}_{2}\left(\mathrm{dapdoH}_{2}\right)\right]$ form pairs through $\pi-\pi$ interactions indicated with dashed dark green lines in Figure 10 (the distance between the planes of neighboring, centrosymmetrically-related molecules is 3.81(1) $\AA$, symmetry: $-x,-y+2,-z+2)$ and $\mathrm{C} 4-\mathrm{H}(\mathrm{C} 4)-\mathrm{I} 2$ hydrogen bonds. Neighboring pairs interact further through $\mathrm{C} 9-\mathrm{H}_{\mathrm{C}}(\mathrm{C} 9) \cdots \mathrm{O} 2$ hydrogen bonds along the [1-10] direction and through $\pi-\pi$ interactions along the $b$ axis, thus forming layers parallel to the (001) plane. The distance between the planes of neighboring, centrosymmetrically-related $(-x,-y+1,-z+2)$ molecules along the $b$ axis direction is 3.49(1) $\AA$, and this interaction is indicated with dashed light green lines in Figure 10. Metric parameters of the hydrogen bonds are listed in Table S1.

Compound 5 crystallizes in the orthorhombic space group Pcnb. As the complex possesses a 2-fold axis of symmetry passing through Cd1, N2 and C6 atoms (Wyckoff position 4c: $\left.0, \frac{1}{4}, z\right)$, the asymmetric unit of the cell contains $\frac{1}{2}$ of the $\left[\mathrm{CdI}_{2}\left(\mathrm{~L}^{\prime} \mathrm{H}_{2}\right)\right]$ molecule. The 5-coordinate $\mathrm{Cd}^{\mathrm{II}}$ atom forms coordination bonds with the two terminal iodo groups 
(I1, I1 $\left.{ }^{\prime}\right)$, the two imino nitrogen atoms $\left(\mathrm{N} 1, \mathrm{~N} 1^{\prime}\right)$ and the pyridyl nitrogen atom (N2) of the transformed ligand $\mathrm{L}^{\prime} \mathrm{H}_{2}$. Thus, the organic molecule behaves as a 1.00111 ligand participating in two 5-membered chelating rings with the metal center. The terminal Cd ${ }^{\mathrm{II}}$-I bonds [2.738(1) $\AA$ ] are almost identical to those of 4.2EtOH [average 2.727(1) $\AA$ ], a consequence of the 5-coordination of $\mathrm{Cd}^{\mathrm{II}}$ in the two complexes. As in $4 \cdot 2 \mathrm{EtOH}$, the coordination polyhedron of the metal ion in 5 is extremely distorted, a fact primarily arising from the small N1-Cd1-N2 and N1 ${ }^{\prime}-\mathrm{Cd} 1-\mathrm{N} 2\left[68.2(1)^{\circ}\right]$ coordination angles of the chelating "parts" of $\mathrm{L}^{\prime} \mathrm{H}_{2}$. The polyhedron can be better described as a very distorted trigonal bipyramid with atoms $\mathrm{N} 1$ and $\mathrm{N} 1$ ' occupying the axial positions. Neighboring molecules of 5 interact through pairs of $\mathrm{C}$ (methyl)- $\mathrm{H}^{\cdots} \pi$ interactions forming chains parallel to the $a$ axis; neighboring chains interact through $\mathrm{C}$ (methyl)- $\mathrm{H} \cdots$ I hydrogen bonds creating layers parallel to the (001) crystallographic plane (Figure S12, Table S2). Compound 5 is the first structurally characterized complex of any metal containing the new ligand $\mathrm{L}^{\prime} \mathrm{H}_{2}$.

Complexes 2 and $4 \cdot 2 \mathrm{EtOH}$ are the first structurally characterized $\mathrm{Cd}(\mathrm{II})$ complexes with 3 paoH and dapdoH $\mathrm{H}_{2}$ ligands, respectively. Compounds 1 and 3 join a small family of structurally characterized $\mathrm{Cd}$ (II) complexes of $2 \mathrm{paoH}$ and $4 \mathrm{paoH}$ [55-60], mainly reported by Fonari's group in a series of excellent crystal engineering studies. The $2 \mathrm{paoH}$ complexes reported are $\left[\mathrm{Cd}\left(\mathrm{O}_{2} \mathrm{CMe}\right)_{2}(2 \mathrm{paoH})_{2}\right]$ [50], $\left.\left[\mathrm{Cd}_{2}(\mathrm{suc})(2 \mathrm{paoH})_{4}\left(\mathrm{H}_{2} \mathrm{O}\right)_{2}\right]\right]\left(\mathrm{BF}_{4}\right)_{2}[56]$, $\left\{\left[\mathrm{Cd}(\mathrm{suc})(2 \mathrm{paoH})_{2}\right]\right\}_{\mathrm{n}}[56],\left[\mathrm{Cd}\left(\mathrm{HCO}_{2}\right)_{2}(2 \mathrm{paoH})_{2}\right]$ [59], \{[Cd(1,4-bdc)(2paoH)]·1.5DMF $\}_{\mathrm{n}}$ [59], $\left\{\left[\mathrm{Cd}\left(\mathrm{SO}_{4}\right)(2 \mathrm{paoH})\left(\mathrm{H}_{2} \mathrm{O}\right)\right]\right\}_{\mathrm{n}}[59],\left\{\left[\mathrm{Cd}(\mathrm{fum})(2 \mathrm{paoH})_{2}\right]\right\}_{\mathrm{n}}[60],\{[\mathrm{Cd}(1,3-\mathrm{bdc})(2 \mathrm{paoH})]\}_{\mathrm{n}}[60]$, where suc ${ }^{2-}$ is the succinate(-2) ligand, 1,4-bdc ${ }^{2-}$ is the 1,4-benzenedicarboxylate(-2) ligand, fum ${ }^{2-}$ is the fumarate(-2) ligand and $1,3-\mathrm{bdc}^{2-}$ is the 1,3-benzedicarboxylate(-2) ligand. In all these complexes, the $2 \mathrm{paoH}$ molecule behaves as a $\mathrm{N}, \mathrm{N}^{\prime}$-bidentate chelating (1.011) ligand. The 4paoH Cd(II) complexes reported are $\left\{\left[\mathrm{Cd}(\mathrm{mal})(4 \mathrm{paoH})\left(\mathrm{H}_{2} \mathrm{O}\right)\right]\right\}_{n}[56]$, $\left\{\left[\mathrm{Cd} \text { (adi) }(4 \mathrm{paoH})_{2}\right] \cdot \mathrm{DMF}\right\}_{\mathrm{n}}[56],\left\{\left[\mathrm{Cd}\left(\mathrm{SO}_{4}\right)(4 \mathrm{paoH})_{2}\left(\mathrm{H}_{2} \mathrm{O}\right)_{2}\right]\right\}_{\mathrm{n}}[57],\left[\mathrm{Cd}_{2}\left(\mathrm{O}_{2} \mathrm{CMe}\right)_{4}(4 \mathrm{paoH})_{4}\right]$ $\cdot 4 \mathrm{H}_{2} \mathrm{O}$ [58], [Cd $\left.\left(\mathrm{O}_{2} \mathrm{CMe}\right)_{2}(4 \mathrm{paoH})_{3}\right] \cdot 3 \mathrm{H}_{2} \mathrm{O}[58],\left\{\left[\mathrm{Cd}(1,3-\text { bdc })(4 \mathrm{paoH})\left(\mathrm{H}_{2} \mathrm{O}\right)_{2}\right] \cdot \text { DMF. } \mathrm{H}_{2} \mathrm{O}\right\}_{n}$ [60], $\left\{\left[\mathrm{Cd}(1,4-\mathrm{bdc})(4 \mathrm{paoH})_{2}\left(\mathrm{H}_{2} \mathrm{O}\right)\right] \cdot \mathrm{DMF}\right\}_{\mathrm{n}}[60]$ and $\left\{\left[\mathrm{Cd}(1,4-\mathrm{bdc})(4 \mathrm{paoH})_{2}\right] \cdot \mathrm{DMF}\right\}_{\mathrm{n}}[60]$, where $\mathrm{mal}^{2-}$ is the malonate(-2) ligand and $\mathrm{adi}^{2-}$ is the adipate(-2) ligand. As in 3, in all of the just mentioned complexes, 4paoH behaves as an N(pyridyl) [1.010] monodentate ligand. It seems that this monodentate coordination mode is the preferable one for $\mathrm{Cd}(\mathrm{II})$.

\section{Experimental Section}

\subsection{Materials and Spectrocopic- Physical Measurements}

Experimental manipulations were carried out under aerobic conditions. Deionized water was received from the in-house facility. Solvents and reagents were purchased from Sigma-Aldrich (Tanfrichen, Germany) and Alfa Aesar (Karlsruhe, Germany), and used as received without extra purification. The free ligands 2,6-diacetylpyridine dioxime $\left(\mathrm{dapdoH}_{2}\right.$, Figure 1) and 2,6-pyridyl-diamidoxime $\left(\mathrm{LH}_{4}\right.$, Figure 1) were synthesized by following the procedures published in the literature $[61,62]$. The products were recrystallized from refluxing $\mathrm{EtOH}$, and their yields were $>70 \%$. The purity of the free organic ligands was checked by microanalyses and ${ }^{1} \mathrm{H}$ NMR spectroscopy.

Carbon, hydrogen and nitrogen microanalyses were performed by the Instrumental Analysis Center of the University of Patras. FT-IR spectra were recorded using a PerkinElmer spectrometer, model 16PC, manufactured by Perkin-Elmer (Waltham, MA, USA); the samples were in the form of $\mathrm{KBr}$ pellets prepared under pressure. FT-Raman spectra were obtained in an EQUINOX spectrometer to which a Bruker (D) FRA-106/S component had been attached (Bruker, Karlsruhe, Germany); an R510 diode-pumped Nd:YAG laser at $1064 \mathrm{~nm}$ was used for Raman excitation with a maximum laser power of $500 \mathrm{~mW}$ on the sample, utilizing an average of 100 scans at $4 \mathrm{~cm}^{-1}$ resolution. ${ }^{1} \mathrm{H}$ and ${ }^{13} \mathrm{C}$ NMR spectra were recorded on a Bruker Avance DPX spectrometer (Bruker AVANCE, Billerica, MA, USA) at resonance frequencies of $400.13 \mathrm{MHz}\left({ }^{1} \mathrm{H}\right)$ and $100.62 \mathrm{MHz}\left({ }^{13} \mathrm{C}\right)$; the signals of the solvent $\left(\mathrm{d}_{6}\right.$-DMSO) were used as a reference. Conductivity measurements were performed at room temperature $\left(23-25{ }^{\circ} \mathrm{C}\right)$ in DMSO with a Metrohm-Herisau E-527 bridge (Herisau, Switzerland) and a cell of standard constant; the concentration of the solution was $10^{-3} \mathrm{M}$. 


\subsection{Preparation of the Complexes}

A variety of reaction systems involving various anions of the $\mathrm{Cd}(\mathrm{II})$ sources, and different solvent media, reagent ratios, crystallization techniques, reaction times and temperatures were employed before finding the optimized conditions described below.

$\left[\mathrm{CdI}_{2}(2 \mathrm{paoH})_{2}\right]$ (1): A solution of $\mathrm{CdI}_{2}(0.055 \mathrm{~g}, 0.20 \mathrm{mmol})$ in $\mathrm{MeCN}(1 \mathrm{~mL})$ was added to a solution of $2 \mathrm{paoH}(0.049 \mathrm{~g}, 0.40 \mathrm{mmol})$ in $\mathrm{CH}_{2} \mathrm{Cl}_{2}(3 \mathrm{~mL})$. The resulting colorless solution was stirred for $10 \mathrm{~min}$, filtered and was allowed to slowly evaporate at room temperature. X-ray quality, colorless crystals of the product were obtained within $3 \mathrm{~d}$. The crystals were collected by filtration, washed with cold $\mathrm{MeOH}(2 \times 0.5 \mathrm{~mL})$ and $\mathrm{Et}_{2} \mathrm{O}$ $(2 \times 2 \mathrm{~mL})$, and dried in vacuo over anhydrous $\mathrm{CaCl}_{2}$. Yield: $74 \%$. Anal. Calcd. (\%) for $\mathrm{C}_{12} \mathrm{H}_{12} \mathrm{~N}_{4} \mathrm{CdI}_{2} \mathrm{O}_{2}$ : C, 23.61; H, 1.99; N, 9.18. Found (\%): C, 23.24; $\mathrm{H}, 1.91 ; \mathrm{N}, 9.15$. IR $\left(\mathrm{KBr}, \mathrm{cm}^{-1}\right)$ : 3324 w, 3314 w, 3304 w, 3228 wb, 3090 w, 3060 w, 1640 m, 1594 s, 1480 s, 1442 s, 1480 s, 1442 s, 1408 s, 1306 m, 1290 s, 1282 sh, 1256 s, 1212 m, 1150 m, 1106 m, 1052 w, 1004 s, 960 m, 932 s, 886 s, 774 s, 742 m, 672 s, 646 m, 600 m, 568 m, 510 s, 466 w. Raman (cm $\left.{ }^{-1}\right)$ : 3054 m, 3003 w, 1562 m, 1642 s, 1632 m, 1611 m, 1570 s, 1550 s, 1498 m, 1468 m, 1427 w, 1406 m, 1304 w, 1243 w, 1222 s, 1212 s, 1171 w, 1099 m, 1048 w, 1017 m, 925 w, 895 w, $772 \mathrm{w}, 670 \mathrm{w}, 506 \mathrm{w}, 403 \mathrm{~m}, 301 \mathrm{~m}, 219 \mathrm{~m}, 137 \mathrm{~s}, 127 \mathrm{~s}, 117 \mathrm{~s}, 97 \mathrm{~m}, 76 \mathrm{~m}, 66 \mathrm{w} .{ }^{1} \mathrm{H}$ NMR $\left(\mathrm{d}_{6}\right.$-DMSO, $\left./ \mathrm{ppm}\right): 10.97(\mathrm{~s}, 2 \mathrm{H}), 7.91(\mathrm{~d}, 2 \mathrm{H}), 7.42(\mathrm{~s}, 2 \mathrm{H}), 7.15(\mathrm{mt}, 4 \mathrm{H}), 6.72(\mathrm{t}, 2 \mathrm{H})$. ${ }^{13} \mathrm{C}$ NMR (d ${ }_{6}$-DMSO, $\left.\delta / \mathrm{ppm}\right): 173.1,152.3,149.6,137.4,124.6,120.5 . \Lambda_{\mathrm{M}}\left(\mathrm{DMSO}, 10^{-3} \mathrm{M}\right.$, $\left.25^{\circ} \mathrm{C}\right)=4 \mathrm{~S} \mathrm{~cm}^{2} \mathrm{~mol}^{-1}$.

$\left\{\left[\mathrm{CdI}_{2}(3 \mathrm{paoH})_{2}\right]\right\}_{n}(2):$ A solution of $\mathrm{CdI}_{2}(0.110 \mathrm{~g}, 0.40 \mathrm{mmol})$ in $\mathrm{EtOH}(1 \mathrm{~mL})$ was slowly added to a slightly warm $\left(\sim 40{ }^{\circ} \mathrm{C}\right)$ solution of 3 paoH $(0.098 \mathrm{~g}, 0.80 \mathrm{mmol})$ in the same solvent $(3 \mathrm{~mL})$. The resulting colorless solution was stirred for $15 \mathrm{~min}$ and stored in a closed vial at $5{ }^{\circ} \mathrm{C}$. X-ray quality, colorless crystals of the product were precipitated within $24 \mathrm{~h}$. The crystals were collected by filtration, washed with cold EtOH $(0.5 \mathrm{~mL})$ and $\mathrm{Et}_{2} \mathrm{O}(2 \times 1 \mathrm{~mL})$, and dried in air. The average yield was $65 \%$. Anal. Calcd. (\%) for $\mathrm{C}_{12} \mathrm{H}_{12} \mathrm{~N}_{4} \mathrm{CdI}_{2} \mathrm{O}_{2}$ : C, 23.61; $\mathrm{H}, 1.99 ; \mathrm{N}, 9.18$. Found (\%): C, 23.90; H, 1.97; N, 9.35. IR $\left(\mathrm{KBr}, \mathrm{cm}^{-1}\right)$ : $3488 \mathrm{mb}, 1624 \mathrm{w}, 1596 \mathrm{w}, 1574 \mathrm{w}, 1482 \mathrm{~m}, 1424 \mathrm{~m}, 1386 \mathrm{w}, 1330 \mathrm{w}, 1252 \mathrm{~s}$, 1228 sh, 1186 m, 1118 w, 1090 w, 1050 w, 952 s, 936 sh, 882 s, 804 m, 690 s, 642 m, 534 m, 472 mb. Raman (cm $\left.{ }^{-1}\right): 3067$ m, 1642 s, 1597 m, 1578 m, 1391 w, 1331 w, 1264 w, 1233 w, $1185 \mathrm{w}, 1050 \mathrm{w}, 1032 \mathrm{~m}, 884 \mathrm{w}, 643 \mathrm{w}, 380 \mathrm{w}, 292 \mathrm{w}, 245 \mathrm{sh} .{ }^{1} \mathrm{H}$ NMR $\left(\mathrm{d}_{6}-\mathrm{DMSO}, \delta / \mathrm{ppm}\right)$ : $11.57(\mathrm{sb}, 2 \mathrm{H}), 8.75(\mathrm{dd}, 2 \mathrm{H}), 8.57(\mathrm{dd}, 2 \mathrm{H}), 8.21(\mathrm{~s}, 2 \mathrm{H}), 8.00(\mathrm{mt}, 2 \mathrm{H}), 7.45(\mathrm{dd}, 2 \mathrm{H}) . \Lambda_{\mathrm{M}}$ (DMSO, $10^{-3} \mathrm{M}, 25^{\circ} \mathrm{C}$ ) $=6 \mathrm{~S} \mathrm{~cm}^{2} \mathrm{~mol}^{-1}$.

$\left\{\left[\mathrm{CdI}_{2}(4 \mathrm{paoH})_{2}\right]\right\}_{n}$ (3): A solution of $\mathrm{CdI}_{2}(0.055 \mathrm{~g}, 0.20 \mathrm{mmol})$ in $\mathrm{Me}_{2} \mathrm{CO}(1 \mathrm{~mL})$ was slowly added to a solution of $4 \mathrm{paoH}(0.049 \mathrm{~g}, 0.40 \mathrm{mmol})$ in the same solvent $(3 \mathrm{~mL})$. The resulting colorless solution was stirred and stored at $-10{ }^{\circ} \mathrm{C}$ for 1 month. No solid was noticed and the solution was layered with $\mathrm{Et}_{2} \mathrm{O}(2 \mathrm{~mL})$ and allowed to stand undisturbed at room temperature. Slow mixing gave crystals suitable for single-crystal, $\mathrm{X}$-ray crystallography within $12 \mathrm{~d}$. The crystals were collected by filtration, washed with cold $\mathrm{EtOH}$ $(0.5 \mathrm{~mL})$ and $\mathrm{Et}_{2} \mathrm{O}(2 \times 1 \mathrm{~mL})$, and dried in air overnight. Yield: $78 \%$. Anal. Calcd. (\%) for $\mathrm{C}_{12} \mathrm{H}_{12} \mathrm{~N}_{4} \mathrm{CdI}_{2} \mathrm{O}_{2}$ : C, 23.61; H, 1.99; N, 9.18. Found (\%): C, 23.87; H, 1.90; N, 9.07. IR $\left(\mathrm{KBr}, \mathrm{cm}^{-1}\right)$ : $3420 \mathrm{sb}, 3010 \mathrm{w}, 1638 \mathrm{wb}, 1610 \mathrm{~m}, 1505 \mathrm{w}, 1498 \mathrm{sh}, 1420 \mathrm{~m}, 1398 \mathrm{~m}, 1264 \mathrm{~s}$, $1224 \mathrm{sh}, 1060 \mathrm{wb}, 1010 \mathrm{w}, 962 \mathrm{~s}, 936 \mathrm{~m}, 888 \mathrm{w}, 814 \mathrm{~m}, 658 \mathrm{~m}, 564 \mathrm{w}, 510 \mathrm{~s}, 486 \mathrm{~m}, 404 \mathrm{~m}$. Raman (cm $\left.{ }^{-1}\right)$ : 3071 m, 3059 w, 1622 sh, 1613 s, 1543 w, 1399 w, 1327 w, 1269 w, 1240 w,

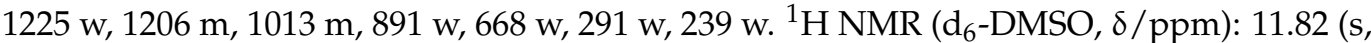
$2 \mathrm{H}), 8.60(\mathrm{dd}, 4 \mathrm{H}), 8.18(\mathrm{~s}, 2 \mathrm{H}), 7.55(\mathrm{dd}, 4 \mathrm{H}) . \Lambda_{\mathrm{M}}\left(\mathrm{DMSO}, 10^{-3} \mathrm{M}, 25^{\circ} \mathrm{C}\right)=5 \mathrm{~S} \mathrm{~cm}^{2} \mathrm{~mol}^{-1}$.

$\left[\mathrm{CdI}_{2}\left(\right.\right.$ dapdoH $\left.\left.\mathrm{H}_{2}\right)\right] \cdot 2 \mathrm{EtOH}(4 \cdot 2 \mathrm{EtOH}):$ A solution of $\mathrm{CdI}_{2}(0.055 \mathrm{~g}, 0.20 \mathrm{mmol})$ in $\mathrm{EtOH}$ $(1 \mathrm{~mL})$ was added to a slurry of dapdoH $_{2}(0.039 \mathrm{~g}, 0.20 \mathrm{mmol})$ in the same solvent $(6 \mathrm{~mL})$. The resulting pale yellow suspension was filtered to remove a very small quantity of the ligand. The filtrate was stirred for 2-3 min and stored in a closed vial at room temperature. X-ray quality, colorless crystals of the product were formed within $24 \mathrm{~h}$ which were collected by filtration, washed with cold $\mathrm{EtOH}(0.5 \mathrm{~mL})$ and $\mathrm{Et}_{2} \mathrm{O}(2 \times 1 \mathrm{~mL})$, and dried in vacuo over anhydrous $\mathrm{CaCl}_{2}$. Yield: $28 \%$. The sample was analyzed without lattice EtOH molecules. Anal. Calcd. (\%) for $\mathrm{C}_{9} \mathrm{H}_{11} \mathrm{~N}_{3} \mathrm{CdI}_{2} \mathrm{O}_{2}$ : C, 19.32; $\mathrm{H}, 1.99 ; \mathrm{N}, 7.51$. Found (\%): C, 19.35; 
H, 2.08; N, 8.11 IR (KBr, cm $\left.{ }^{-1}\right)$ : 3422 s, 3178 mb, 3084 w, 3036 w, 2922 w, 1594 m, 1472 m, 1364 m, 1316 w, 1292 m, 1264 m, 1194 w, 1156 w, 1130 w, 1038 s, 950 m, 830 w, 808 m, 732w, 690 m, 654 w, 554 m, 508 w, 428 w. Raman (cm $\left.{ }^{-1}\right): 3076$ m, 3065 sh, 2932 m, 1638 m, 1589sh, 1564 s, 1476 sh, 1464 w, 1429 w, 1358 m, 1314 w, 1262 w, 1129 w, 1015 s, 832 w, 760 w, 656 w, 448 w. ${ }^{1} \mathrm{H}$ NMR (d $6^{-}$DMSO, $\left.\delta / p p m\right): 11.51(\mathrm{~s}, 2 \mathrm{H}), 7.80(\mathrm{mt}, 3 \mathrm{H}), 2.25(\mathrm{~s}, 6 \mathrm{H}) . \Lambda_{\mathrm{M}}(\mathrm{DMSO}$, $\left.10^{-3} \mathrm{M}, 25^{\circ} \mathrm{C}\right)=8 \mathrm{~S} \mathrm{~cm}^{2} \mathrm{~mol}^{-1}$.

$\left[\mathrm{CdI}_{2}\left(\mathrm{~L}^{\prime} \mathrm{H}_{2}\right)\right]$ (5): A solution of $\mathrm{CdI}_{2}(0.055 \mathrm{~g}, 0.20 \mathrm{mmol})$ in $\mathrm{EtOH}(1 \mathrm{~mL})$ was added to a solution of $\mathrm{LH}_{4}(0.039 \mathrm{~g}, 0.20 \mathrm{mmol})$ in the same solvent $(7 \mathrm{~mL})$. The resulting suspension was filtered to remove a small quantity of a precipitated material (5a). The filtrate was stirred for 2-3 min and stored in a closed vial at room temperature for $4 \mathrm{~d}$. The color of the reaction solution (filtrate) turned gradually to pink-pale violet during this time. This pink solution was placed at $5{ }^{\circ} \mathrm{C}$, and X-ray quality, colorless crystals (from a pink solution!) were grown within a period of 7-8 d. The crystals were collected by filtration, washed with cold $\mathrm{EtOH}(0.5 \mathrm{~mL})$ and $\mathrm{Et}_{2} \mathrm{O}(2 \times 1 \mathrm{~mL})$, and dried in air overnight. Yield: $41 \%$. The sample 5a was analyzed as $\left[\mathrm{CdI}_{2}\left(\mathrm{LH}_{4}\right)\right]$. Anal. Calcd. (\%) for $\mathrm{C}_{7} \mathrm{H}_{9} \mathrm{~N}_{5} \mathrm{CdI}_{2} \mathrm{O}_{2}: \mathrm{C}, 14.97$; $\mathrm{H}, 1.62 ; \mathrm{N}, 12.48$. Found (\%): C, 14.60; H, 1.67; N, 12.63. IR spectrum $\left(\mathrm{KBr}, \mathrm{cm}^{-1}\right)$ for $5 \mathrm{a}$ : 3480 s, 3432 sb, 3372 sb, 3070 wb, 1654 s, 1604 sh, 1582 s, 1484 m, 1402 m, 1340 s, 1214 w, 1155 w, 1105 w, 1076 s, 1018 m, 986 s, 902 m, 810 s, 732 m, 696 s, 656 m, 522 mb, 460 w, 446 w. ${ }^{1} \mathrm{H}$ NMR spectrum $\left(\mathrm{d}_{6}\right.$-DMSO, $\left.\delta / \mathrm{ppm}\right)$ for 5a: $9.85(\mathrm{~s}, 2 \mathrm{H}), 7.81(\mathrm{mt}, 3 \mathrm{H}), 6.32(\mathrm{sb}$, $4 \mathrm{H})$. Analytical data for the product 5: Anal. Calcd. (\%) for $\mathrm{C}_{11} \mathrm{H}_{15} \mathrm{~N}_{3} \mathrm{CdI}_{2} \mathrm{O}_{2}$ : C, $22.49 ; \mathrm{H}$, 2.58; N, 7.15. Found (\%): C, 28.93; H, 2.71; N, 7.07. IR spectrum (KBr, $\left.\mathrm{cm}^{-1}\right)$ for 5: $3444 \mathrm{mb}$, $3292 \mathrm{mb}, 2984 \mathrm{~m}, 1648 \mathrm{~m}, 1578 \mathrm{~s}, 1458 \mathrm{~m}, 1404 \mathrm{~m}, 1378 \mathrm{~m}, 1344 \mathrm{~s}, 1290 \mathrm{~m}, 1198 \mathrm{~m}, 1146 \mathrm{~s}$, $1106 \mathrm{~m}, 1018 \mathrm{~m}, 930 \mathrm{w}, 838 \mathrm{~m}, 796 \mathrm{~m}, 748 \mathrm{~m}, 696 \mathrm{w}, 660 \mathrm{~m}, 434 \mathrm{w}$. The $\Lambda_{\mathrm{M}}$ values of both 5 and $5 \mathrm{a}$ in DMSO are $\sim 5 \mathrm{~S} \mathrm{~cm}^{2} \mathrm{~mol}^{-1}$.

\subsection{Single-Crystal X-ray Crystallography}

Colorless crystals of $1,2,3,4 \cdot 2 \mathrm{EtOH}$ and 5 were taken from the mother liquor and immediately cooled to $160(1,3,4 \cdot 2 \mathrm{EtOH}, 5)$ or 170 (2) K. Diffraction data were collected on a Rigaku R-AXIS Image Plate diffractometer (Rigaku Americas Corporation, The Woodlands, TX, USA; European Department at Karlsruhe, Germany) using graphite-monochromated $\mathrm{Cu} \mathrm{Ka}(1,2)$ or Mo Ka $(3,4 \cdot 2 \mathrm{EtOH}, 5)$ radiations. Data collection ( $\omega$-scans) and processing (cell refinement, data reduction, and empirical/numerical absorption correction) were performed using the CrystalClear program package [63]. The structures were solved by direct methods using SHELXS, ver. 2013/1 [64] and refined by full-matrix least-squares techniques on $F^{2}$ with SHELXL, ver. 2014/6 [65]. Most $\mathrm{H}$ atoms were introduced at calculated positions as riding on their corresponding bonded atoms. All non- $\mathrm{H}$ atoms were refined anisotropically. Plots of the structures were drawn using the Diamond 3 program package [66].

Crystallographic data have been deposited with the Cambridge Crystallographic Data Center, Nos 2142693 (1), 2142694 (2), 2142695 (3), 2142696 (4·2EtOH) and 2142697 (5). Copies of the data can be obtained free of charge upon application to CCDC, 12 Union Road, Cambridge, CB2 1EZ, UK: Tel.: +(44)-1223-762910; Fax: +(44)-1223-336033; E-mail: deposit@ccdc.cam.ac.uk.

\section{Conclusions in Brief}

According to our opinion, the important chemical messages of this work are: (a) The reported complexes enrich the coordination chemistry of 2-pyridyl oximes, especially that with $\mathrm{Cd}(\mathrm{II})$. (b) The molecular structures and supramolecular features of the complexes are interesting; and (c) The interesting Cd(II)-assisted/promoted $\mathrm{LH}_{4} \rightarrow \mathrm{L}^{\prime} \mathrm{H}_{2}$ transformation has been observed for the first time and this is a new, welcome example in the area of the reactivity of coordinated amidoximes.

From the viewpoint of the solvent extraction of toxic $\mathrm{Cd}(\mathrm{II})$ using 2-pyridyl oximes as extractants (which stimulated the present efforts) our inorganic chemistry approach has firmly confirmed the molecular basis of the excellent extraction ability of 2PC12 and 
2PC14, and the poor one for 4PC12, 4PC14. With the drawbacks mentioned in Introduction, the very good extraction ability of the 2-pyridyl ketoximes can be attributed to the chelating nature of the extractants as structurally proven by the $2 \mathrm{paoH}$-containing complex 1 ; this chelating behavior results in thermodynamically stable complexes of $\mathrm{Cd}(\mathrm{II})$ with the extractant, favoring this process. The monodentate coordination of 4-pyridyl ketoximes (as structurally proven in the 4paoH-containg compound 3) seems to be responsible for the poor performance of $4 \mathrm{PC} 12$ and 4PC14. In an analogous manner (as proven in the 3 paoH-conataining compound 2), extractants such as 3PC12 and 3PC14 (i.e., those containing the oxime group at position 3 of the pyridyl ring; Figure 1) are predicted to disfavor the extraction process; such "real" experiments are not available.

We tentatively propose that the structurally established tridentate chelating character of dapdoH $\mathrm{H}_{2}$ towards $\mathrm{Cd}$ (II) in complex $4 \cdot 2 \mathrm{EtOH}$ and the presumable such behavior of $\mathrm{LH}_{4}$ in complex 5a could be exploited to develop extractants consisting of one pyridyl ring and two oxime groups that contain long alkyl components at the 2- and 6-positions, or even to carry out experiments with the bis(amidoxime) compound $\mathrm{LH}_{4}$ (or better with derivatives containing aliphatic substituents on the pyridyl ring to ensure good solubility in non-polar organic solvents). The decomposition of 4 in DMSO (as evidenced by its ${ }^{1} \mathrm{H}$ NMR spectrum in $\mathrm{d}_{6}$-DMSO, see Section 2.2) should not be disappointing, since this solvent is an efficient donor forming complexes with $\mathrm{Cd}(\mathrm{II})$ and favoring decomposition; the presence of coordinated dapdoH $\mathrm{H}_{2}$-containing species in $\mathrm{CDCl}_{3}$ (albeit evidenced by poor quality ${ }^{1} \mathrm{H} \mathrm{NMR}$ spectra) is a good sign towards the use of 2,6-pyridyl dioximes as extractants for toxic Cd(II). The scientific community dealing with solvent extraction experiments might obtain good results working with tridentate dioximes.

Supplementary Materials: The following supporting information can be downloaded: Figure S1: The FT-IR spectrum $\left(\mathrm{KBr} / \mathrm{cm}^{-1}\right)$ of free paoH; Figure S2: The FT-Raman spectrum of free paoH; Figure S3: The FT-Raman spectrum of $\left\{\left[\mathrm{CdI}_{2}(4 \mathrm{paoH})_{2}\right]\right\}_{\mathrm{n}}$ (3); Figure S4: The FT-IR spectrum $\left(\mathrm{KBr} / \mathrm{cm}^{-1}\right)$ of compound $\left[\mathrm{CdI}_{2}\left(\mathrm{LH}_{4}\right)\right](5 \mathrm{a})$; Figure S5: The FT-IR spectrum $\left(\mathrm{KBr} / \mathrm{cm}^{-1}\right)$ of complex $\left[\mathrm{CdI}_{2}\left(\mathrm{~L}^{\prime} \mathrm{H}\right)_{2}\right](5)$; Figure S6: The ${ }^{1} \mathrm{H}$ NMR spectrum ( $\delta / \mathrm{ppm}$ ) of the free ligand 2paoH in $\mathrm{d}_{6}$-DMSO; Figure S7: The ${ }^{1} \mathrm{H}$ NMR spectrum $(\delta / \mathrm{ppm})$ of complex $\left\{\left[\mathrm{CdI}_{2}(3 \mathrm{paoH})\right]\right\}_{\mathrm{n}}(2)_{\mathrm{x}}$ in $\mathrm{d}_{6}$-DMSO in the $9.0-7.33 \mathrm{ppm}$ region; Figure S8: The ${ }^{1} \mathrm{H}$ NMR spectrum $(\delta / \mathrm{ppm})$ of compound $\left\{\left[\mathrm{CdI}_{2}(4 \mathrm{paoH})_{2}\right]\right\}_{\mathrm{n}}(3)$ in $\mathrm{d}_{6}-\mathrm{DMSO}$ in the 12.0-7.3 ppm region; Figure S9: A portion of one chain, parallel to the crystallographic direction [101], in the crystal structure of $\left[\mathrm{CdI}_{2}(2 \mathrm{paoH})_{2}\right](\mathbf{1})$. The thick dashed orange and green lines represent the intramolecular $\mathrm{O} 1-\mathrm{H}(\mathrm{O} 1) \cdots \mathrm{I} 1^{\prime}$ and $\mathrm{O}^{\prime}-\mathrm{H}\left(\mathrm{O1}^{\prime}\right) \cdots \mathrm{I} 1$ hydrogen bonds $\left[\left(^{\prime}\right)=-x, y,-z+1 / 2\right]$ and the $\pi-\pi$ interactions, respectively; Figure S10: Layers of chains parallel to the (110) plane in the crystal structure of $\left\{\left[\mathrm{CdI}_{2}(3 \mathrm{paoH})_{2}\right]\right\}_{\mathrm{n}}$ (2). The layers are formed through $\mathrm{O}-\mathrm{H} \cdots$ I hydrogen bonds (thick dashed cyan lines); see text for more details; Figure S11: Layers of chains parallel to the (110) plane in the crystal structure of $\left\{\left[\mathrm{CdI}_{2}(4 \mathrm{paoH})_{2}\right]\right\}_{n}$ (3). The layers are formed through $\mathrm{O}-\mathrm{H} \cdots$ I hydrogen bonds (thick dashed cyan lines); see text for the metric parameters; Figure S12: Formation of chains parallel to the a axis and layers parallel to the (001) crystallographic plane in the crystal structure of complex $\left[\mathrm{CdI}_{2}\left(\mathrm{~L}^{\prime} \mathrm{H}_{2}\right)\right]$ (5). The dashed thick orange line and the cyan lines represent the $\mathrm{C}$ (methyl)$\mathrm{H}^{\cdots} \pi \pi$ and $\mathrm{C}$ (methyl)-H ${ }^{\cdots}$ I interactions; see Table S2 for metric parameters; Table S1: Hydrogen bonding interactions $(\AA, \mathrm{deg})$ in the crystal structure of $\left[\mathrm{CdI}_{2}\left(\mathrm{dapdoH}_{2}\right)\right] \cdot 2 \mathrm{EtOH}(4 \cdot 2 \mathrm{EtOH})$; Table S2: Hydrogen bonding interactions ( $(\AA, \mathrm{deg})$ in the crystal structure of $\left[\mathrm{CdI}_{2}\left(\mathrm{~L}^{\prime} \mathrm{H}_{2}\right)\right](5)$.

Author Contributions: A.R., Z.G.L. and V.A. contributed towards the synthesis, crystallization, and conventional characterization of the complexes. Z.G.L. also contributed to the interpretation of the results and performed the Raman experiments. C.P.R. and V.P. collected single-crystal X-ray crystallographic data, solved the structures, and performed their refinements; the latter also investigated the supramolecular characteristics of the crystal structures and wrote the relevant part of the paper. K.F.K., C.T.C. and S.P.P. coordinated the research and wrote the paper based on the reports of their collaborators. S.P.P. coordinated the cooperation between the teams and submitted the manuscript. All the authors exchanged opinions concerning the progress of the experiments and commented on the various drafts of the paper. All authors have read and agreed to the published version of the manuscript.

Funding: This research received no external funding. 


\section{Data Availability Statement: Not applicable.}

Acknowledgments: The authors thank the MSc program “Analytical Chemistry and Nanotechnology" of the Chemistry Department of the University of Patras (Patras, Greece) for providing us with funding for the purchase of organic solvents. The authors also thank the head of Laboratory of Applied Molecular Spectroscopy (George A. Voyiatzis) at ICE-HT/FORTH for the access to the Raman setup.

Conflicts of Interest: The authors declare no conflict of interest.

\section{References}

1. Wu, T.; Liu, C.; Kong, B.; Sun, J.; Gorig, Y.; Liu, K.; Xie, J.; Pei, A.; Cui, Y. Amidoxime-functionalized macroporous carbon self-refreshed electrode materials for rapid and high-capacity removal of heavy metal from water. ACS Cent. Sci. 2019, 5, 719-726. [CrossRef] [PubMed]

2. Anfar, Z.; Amedlous, A.; Majdoub, M.; Fakir, A.A.E.; Zbair, M.; Ahsaine, H.A.; Jada, A.; Alem, N.E. New amino group functionalized porous carbon for strong chelation ability towards heavy metals. RSC Adv. 2020, 10, 31087-31100. [CrossRef]

3. Kumar Pobi, K.; Mondal, B.; Nayek, S.; Patra, A.K.; Saha, R. Efficient removal of $\mathrm{Hg}^{2+}, \mathrm{Cd}^{2+}$ and $\mathrm{Pb}^{2+}$ from aqueous solution and mixed industrial wastewater using a designed chelating ligand, 2-pyridyl-N-(2'-methylthiophenyl) methyleneimine (PMTPM). Water Sci. Technol. 2019, 7, 1092-1101. [CrossRef] [PubMed]

4. Nordin, N.A.; Rahman, N.A.; Abdullah, A.H. Effective removal of Pb(II) ions by electrospun PAN/Sago lignin-based activated carbon nanofibers. Molecules 2020, 25, 3081. [CrossRef]

5. Elwakeel, K.Z.; Elgarahy, A.M.; Khan, Z.A.; Almugnamisi, M.S.; Al-Bogami, A.S. Perspectives regarding metal/mineralincorporating materials for water purification: With special focus on $\mathrm{Cr}(\mathrm{VI})$ removal. Mater. Adv. 2020, 1, 1546-1574. [CrossRef]

6. Yu, C.-X.; Wang, K.-Z.; Li, X.-J.; Liu, D.; Ma, L.-F.; Liu, L.-L. Highly efficient and facile removal of $\mathrm{Pb}^{2+}$ from water by using a negatively charged azoxy-functionalized metal-organic framework. Cryst. Growth Des. 2020, 20, 5251-5260. [CrossRef]

7. Barzaga, R.; Lestón-Sánchez, L.; Aguilar-Galindo, F.; Estévez-Iternández, O.; Diaz-Tendero, S. Synergy effects in heavy metal ion chelation with aryl- and aroyl-substituted thiourea derivatives. Inorg. Chem. 2021, 60, 11984-12000. [CrossRef]

8. Senel, G.; Ergun, O.N.; Coruh, S.A. Comparison of the properties of natural clinoptilolites and their ion-exchange capacities for silver removal. J. Hazard. Mater. 2010, 180, 486-492.

9. Gao, H.; Zhao, S.; Cheng, X.; Wang, X.; Zheng, L. Removal of anionic azo dyes from aqueous solution using magnetic polymer multi-wall carbon nanotube nanocomposite as adsorbent. Chem. Eng. J. 2013, 223, 84-90. [CrossRef]

10. Li, G.; Zhao, Z.; Liu, J.; Jiang, G. Effective heavy metal removal from aqueous systems by thiol functionalized magnetic mesoporous silica. J. Hazard. Mater. 2011, 192, 277-283. [CrossRef]

11. Kirupha, S.D.; Kalaivani, S.; Vidhyadevi, T. Effective removal of heavy metal ions from aqueous solutions using a new chelating resin poly [2,5-(1,3,4-thiadiazole)-benzalimine]: Kinetic and thermodynamic study. J. Water Reuse Desalin. 2016, 6, 310-324. [CrossRef]

12. Yordanov, A.T.; Roundhill, D.M. Solution extraction of transition and post-transition heavy and precious metals by chelate and macrocyclic ligands. Coord. Chem. Rev. 1998, 170, 93-124. [CrossRef]

13. Tasker, P.A.; Tong, C.C.; Westra, A.N. Co-extraction of cations and anions in base metal recovery. Coord. Chem. Rev. 2007, 251, 1868-1877. [CrossRef]

14. Mazarakioti, E.C.; Beobide, A.S.; Angelidou, V.; Efthymiou, C.G.; Terzis, A.; Psycharis, V.; Voyiatzis, G.A.; Perlepes, S.P. Modeling the solvent extraction of cadmium(II) from aqueous chloride solutions by 2-pyridyl ketoximes: A coordination chemistry approach. Molecules 2019, 24, 2219. [CrossRef]

15. Tarakina, N.V.; Verberck, B. A portrait of cadmium. Nature Chem. 2016, 9, 96. [CrossRef]

16. Frost, J.M.; Kobera, L.; Pialat, A.; Zhang, Y.; Southern, S.A.; Gabidullin, B.; Bryce, D.L.; Murugesu, M. From discrete molecule, to polymer, to MOF: Mapping the coordination chemistry of $\mathrm{Cd}^{\mathrm{II}}$ using ${ }^{113} \mathrm{Cd}$ solid-state NMR. Chem. Commun. 2016, 52, 10680-10683. [CrossRef] [PubMed]

17. Manahan, S.E. Environmental Chemistry, 6th ed.; Lewis Publishers: Boca Raton, FL, USA, 1994.

18. Watson, J.S. Separation Methods for Waste and Environmental Applications; Marcel Dekker: New York, NY, USA, 1999.

19. Kefalas, E.T.; Dakanali, M.; Panagiotidis, P.; Raptopoulou, C.P.; Terzis, A.; Mavromoustakos, T.; Kyrikou, I.; Karligiano, N.; Bino, A.; Salifoglou, A. pH-specific aqueous synthetic chemistry in the binary cadmium(II)-citrate system. Gaining insight into cadmium(II)-citrate speciation with relevance to cadmium toxixity. Inorg. Chem. 2005, 44, 4818-4828. [CrossRef] [PubMed]

20. Montero-Jiménez, M.; Fernández, L.; Alvarado, J.; Criollo, M.; Jadán, M.; Chuquer, D.; Espinoza-Montero, P. Evaluation of the cadmium accumulation in Tamarillo cells (Solanum betaceum) by indirect electrochemical detection of cysteine-rich peptides. Molecules 2019, 24, 2196. [CrossRef] [PubMed]

21. Shiraishi, T.; Tamada, M.; Saito, K.; Sugo, T. Recovery of cadmium from waste of scallop processing with amidoxime adsorbent synthesized by graft-polymerization. Radiat. Phys. Chem. 2003, 66, 43-47. [CrossRef]

22. Alizadeh, T.; Sharifi, A.R.; Canjali, M.R. A new bio-compatible $\mathrm{Cd}^{2+}$-selective nanostructured fluorescent imprinted polymer for cadmium ion sensing in aqueous media and its application in bio imaging in Vero cells. RSC Adv. 2020, 10, 4110-4117. [CrossRef]

23. Waalkes, M.P. Cadmium carcinogenesis. Mutat. Res. 2003, 533, 107-120. [CrossRef] [PubMed] 
24. Tomaszewska, M.; Borowiak-Resterna, A.; Olszanowski, A. Cadmium extraction from chloride solutions with model N-alkyl and N, N-dialkyl-pyridine-carboxamides. Hydrometallurgy 2007, 85, 116-126. [CrossRef]

25. Parus, A.; Wieszczycka, K.; Olszanowski, A. Solvent extraction of cadmium(II) from chloride solutions by pyridyl ketoximes. Hydrometallurgy 2011, 105, 284-289. [CrossRef]

26. Klonowska-Wieszczycka, K.; Olszanowski, A.; Parus, A.; Zydorczak, B. Removal of copper(II) from chloride solutions using hydrophobic pyridyl ketone oximes. Solvent Extr. Ion Exch. 2009, 27, 50-62. [CrossRef]

27. Efthymiou, C.G.; Cunha-Silva, L.; Perlepes, S.P.; Brechin, E.K.; Inglis, R.; Evangelisti, M.; Papatriantafyllopoulou, C. In search of molecules displaying ferromagnetic exchange: Multiple-decker $\mathrm{Ni}_{12}$ and $\mathrm{Ni}_{16}$ complexes from the use of pyridine-2-amidoxime. Dalton Trans. 2016, 45, 17409-17419. [CrossRef] [PubMed]

28. Zahra, M.; Zulfigar, S.; Skene, W.G.; Sarwar, M.I. Efficient uptake of $\mathrm{Cd}(\mathrm{II})$ and $\mathrm{Pb}(\mathrm{II})$ ions by aromatic polyamidoximes. Ind. Eng. Chem. Res. 2018, 57, 15243-15253. [CrossRef]

29. Milios, C.J.; Stamatatos, T.C.; Perlepes, S.P. The coordination chemistry of pyridyl oximes. Polyhedron 2006, 25, 134-194. [CrossRef]

30. Konidaris, K.F.; Polyzou, C.D.; Kostakis, G.E.; Tasiopoulos, A.J.; Roubeau, O.; Teat, S.J.; Manessi-Zoupa, E.; Powell, A.K.; Perlepes, S.P. Metal ion-assisted transformations of 2-pyridinealdoxime and hexafluorophosphate. Dalton Trans. 2012, 41, 2862-2865. [CrossRef]

31. Tsantis, S.T.; Zagoraiou, E.; Savvidou, A.; Raptopoulou, C.P.; Psycharis, V.; Holynska, M.; Perlepes, S.P. Binding of oxime group to uranyl ion. Dalton Trans. 2016, 45, 9307-9319. [CrossRef]

32. Polyzou, C.D.; Koumousi, E.S.; Lada, Z.G.; Raptopoulou, C.P.; Psycharis, V.; Rouzières, M.; Tsipis, A.C.; Mathonière, C.; Clérac, R.; Perlepes, S.P. "Switching on" the single-molecule magnet properties within a series of dinuclear cobalt(III)-dysposium(III) 2-pyridyloximate complexes. Dalton Trans. 2017, 46, 14812-14825. [CrossRef]

33. Papatriantafyllopoulou, C.; Stamatatos, T.C.; Wernsdorfer, W.; Teat, S.J.; Tasiopoulos, A.J.; Escuer, A.; Perlepes, S.P. Combining azide, carboxylate and 2-pyridyloximate ligands in transition-metal chemistry: Ferromagnetic $\mathrm{Ni}_{5}{ }_{5}$ clusters with a bowtie skeleton. Inorg. Chem. 2010, 49, 10486-10496. [CrossRef]

34. Nikolaou, H.; Terzis, A.; Raptopoulou, C.P.; Psycharis, V.; Bekiari, V.; Perlepes, S.P. Unique dinuclear, tetrakis (nitrato-O,O')bridged lanthanide(III) complexes from the use of pyridine-2-amidoxime: Synthesis, structural studies and spectroscopic characterization. J. Surf. Interfaces Mater. 2014, 2, 311-318. [CrossRef]

35. Anastasiadis, N.C.; Polyzou, C.D.; Kostakis, G.E.; Bekiari, V.; Lan, Y.; Perlepes, S.P.; Konidaris, K.F.; Powell, A.K. Dinuclear lanthanide(III)/zinc(II) complexes with methyl 2-pyridyl ketone oxime. Dalton Trans. 2015, 44, 19791-19795. [CrossRef] [PubMed]

36. Stamatatos, T.C.; Foguet-Albiol, D.; Lee, S.-C.; Stoumpos, C.C.; Raptopoulou, C.P.; Terzis, A.; Wernsdorfer, W.; Hill, S.O.; Perlepes, S.P.; Christou, G. "Switching on" the properties of single-molecule magnetism in triangular manganese(III) complexes. J. Am. Chem. Soc. 2007, 129, 9484-9499. [CrossRef]

37. Polyzou, C.D.; Lada, Z.G.; Terzis, A.; Raptopoulou, C.P.; Psycharis, V.; Perlepes, S.P. The fac diastereoisomer of tris (2pyridinealdoximato)cobalt(III) and a cationic cobalt(III) complex containing both the neutral and and anionic forms of the ligand: Synthetic, structural and spectroscopic studies. Polyhedron 2014, 79, 29-36. [CrossRef]

38. Stamatatos, T.C.; Escuer, A.; Abboud, K.A.; Raptopoulou, C.P.; Perlepes, S.P.; Christou, G. Unusual structural types in nickel cluster chemistry from the use of pyridyl oximes: $\mathrm{Ni}_{5}, \mathrm{Ni}_{12} \mathrm{Na}_{2}$, and $\mathrm{Ni}_{14}$ clusters. Inorg. Chem. 2008, 47, 11825-11838. [CrossRef]

39. Polyzou, C.D.; Nikolaou, H.; Raptopoulou, C.P.; Konidaris, K.F.; Bekiari, V.; Psycharis, V.; Perlepes, S.P. Dinuclear lanthanide(III) complexes from the use of methyl 2-pyridyl ketoxime: Synthetic, structural and physical studies. Molecules 2021, $26,1622$. [CrossRef]

40. Papatriantafyllopoulou, C.; Kostakis, G.E.; Raptopoulou, C.P.; Terzis, A.; Perlepes, S.P.; Plakatouras, J.C. Investigation of the $\mathrm{MSO}_{4} \cdot \mathrm{xH}_{2} \mathrm{O}(\mathrm{M}=\mathrm{Zn}, \mathrm{x}=7 ; \mathrm{M}=\mathrm{Cd}, \mathrm{x}=8 / 3) /$ methyl 2-pyridyl ketone oxime reaction system: A novel Cd(II) coordination polymer versus mononuclear and dinuclear Zn(II) complexes. Inorg. Chim. Acta 2009, 362, 2361-2370. [CrossRef]

41. Stamatatos, T.C.; Katsoulakou, E.; Nastopoulos, V.; Raptopoulou, C.P.; Manessi-Zoupa, E.; Perlepes, S.P. Cadmium carboxylate chemistry: Preparation, crystal structure, and thermal and spectroscopic characterization of the one-dimensional polymer $\left[\mathrm{Cd}\left(\mathrm{O}_{2} \mathrm{CMe}\right)\left(\mathrm{O}_{2} \mathrm{CPh}\right)\left(\mathrm{H}_{2} \mathrm{O}\right)_{2}\right]_{\mathrm{n}}$. Z. Nat. B 2003, 58, 1045-1054. [CrossRef]

42. Papatriantafyllopoulou, C.; Raptopoulou, C.P.; Terzis, A.; Janssens, J.F.; Manessi-Zoupa, E.; Perlepes, S.P.; Plakatouras, J.C. Assembly of a helical zinc(II) chain and a two-dimensional cadmium(II) coordination polymer using picolinate and sulfate anions as bridging ligands. Polyhedron 2007, 26, 4053-4064. [CrossRef]

43. Katsoulakou, E.; Konidaris, K.F.; Raptopoulou, C.P.; Psycharis, V.; Manessi-Zoupa, E.; Perlepes, S.P. Synthesis, X-ray structure and characterization of catena-bis (benzoate) bis $\{\mathrm{N}, \mathrm{N}-$ bis(2-hydroxyethyl)-glycinate $\}$ cadmium(II). Bioinorg. Chem. Applic. 2010, 2010, 281932.

44. Katsoulakou, E.; Konidaris, K.F.; Terzis, A.; Raptopoulou, C.P.; Perlepes, S.P.; Manessi-Zoupa, E.; Kostakis, G.E. One-dimensional cadmium(II)/bicinate(-1) complexes: The role of the alkali metal ion used in the reaction medium. Polyhedron 2011, 30, 397-404. [CrossRef]

45. Katsoulakou, E.; Bekiari, V.; Raptopoulou, C.P.; Terzis, A.; Manessi-Zoupa, E.; Powell, A.; Perlepes, S.P. Simultaneous coordination of a ketone by two cadmium(II) ions and conversion to its gem-diolate(-1) form. Inorg. Chem. Commun. 2011, 14, 1057-1060. [CrossRef]

46. Bolotin, D.S.; Bokach, N.A.; Kukushkin, V.Y. Coordination chemistry and metal-involving reactions of amidoximes: Relevance to the chemistry of oximes and oxime ligands. Coord. Chem. Rev. 2016, 313, 62-93. [CrossRef]

47. Bellamy, L.J. The Infrared Spectra of Complex Molecules; Methyen: London, UK, 1966; p. 249. 
48. Dolish, F.R.; Fateley, W.G.; Bentley, F.F. Characteristic Raman Frequencies of Organic Compounds; John Wiley and Sons: New York, NY, USA, 1974; pp. 135-137.

49. Suvitha, A.; Periandy, S.; Boomadevi, S.; Govindarajan, M. Vibrational frequency analysis, FT-IR, FT-Raman, ab initio, HF and DFT studies, NBO, HOMO-LUMO and electronic structure calculations on pycolinaldehyde oxime. Spectrochim. Acta Part A 2014, 117, 216-224. [CrossRef]

50. Lopez-Garriga, J.J.; Babcock, G.T.; Harrison, J.F. Factors influencing the $\mathrm{C}=\mathrm{N}$ stretching frequency in neutral and protonated Schiff's bases. J. Am. Chem. Soc. 1986, 108, 7241-7251. [CrossRef]

51. Nordquest, K.W.; Phelps, D.W.; Little, W.F.; Hodgson, D.J. Metal-metal interactions in linear chains. The structure and characterization of bis (pyridine-2-carboxaldoximinato)platinum(II) dihydrate. J. Am. Chem. Soc. 1976, 98, 1104-1107. [CrossRef]

52. Geary, W.J. The use of conductivity measurements in organic solvents for the characterization of coordination compounds. Coord. Chem. Rev. 1971, 7, 81-122. [CrossRef]

53. Nieuwenhuyzen, M.; Wen, H.; Wilkins, C.J. Cadmium iodide complexes with dimethylsulphoxide, and their crystal structures Z. Anorg. Allg. Chem. 1992, 615, 143-148. [CrossRef]

54. Coxall, R.A.; Harris, S.G.; Henderson, D.K.; Parsons, S.; Tasker, P.A.; Winpenny, R.E.P. Inter-ligand reactions: In situ formation of new polydentate ligands. J. Chem. Soc. Dalton Trans. 2000, 2349-2356. [CrossRef]

55. Shirvan, S.A.; Dezfuli, S.H. Bis(acetate-kO)bis(2-pyridinealdoxime-k ${ }^{2} \mathrm{~N} \mathrm{~N}^{\prime}$ )cadmium. Acta Cryst. E. 2012, 68, m1080-m1081. [CrossRef]

56. Croitor, L.; Coropceanu, E.B.; Masunov, A.E.; Rivera-Jacquez, H.J.; Siminel, A.V.; Zelentsov, V.I.; Datsko, T.Y.; Fonari, M.S. Polymeric luminescent $\mathrm{Zn}(\mathrm{II})$ and $\mathrm{Cd}(\mathrm{II})$ dicarboxylates decorated by oxime ligands: Tuning the dimensionality and adsorption capacity. Cryst. Growth Des. 2014, 14, 3935-3948. [CrossRef]

57. Croitor, L.; Coropseanu, E.B.; Masunov, A.E.; Rivera-Jacquez, H.J.; Siminel, A.V.; Fonari, M.S. Mechanism of nonlinear optical enhancement and supramolecular isomerism in $1 \mathrm{D}$ polymeric $\mathrm{Zn}(\mathrm{II})$ and $\mathrm{Cd}(\mathrm{II})$ sulfates with pyridine-4-aldoxime ligands. J. Phys. Chem. C 2014, 118, 9217-9227. [CrossRef]

58. Coropseanu, E.B.; Croitor, L.; Siminel, A.V.; Fonari, M.S. Preparation, structural characterization and luminescence studies of mono- and binuclear $\mathrm{Zn}(\mathrm{II})$ and $\mathrm{Cd}(\mathrm{II})$ acetates with pyridine-4-aldoxime and pyridine-4-amidoxime ligands. Polyhedron 2014, 75, 73-80. [CrossRef]

59. Croitor, L.; Coropceanu, E.B.; Siminel, A.V.; Masunov, A.E.; Fonari, M.S. From discrete molecules to one-dimensional coordination polymers containing $\mathrm{Mn}(\mathrm{II}), \mathrm{Zn}(\mathrm{II})$ or $\mathrm{Cd}(\mathrm{II})$ pyridine-2-aldoxime building unit. Polyhedron 2013, 60, 140-150. [CrossRef]

60. Croitor, L.; Coropceanu, E.B.; Duca, G.; Siminel, A.V.; Fonari, M.S. Nine Mn(II), Zn(II) and Cd(II) mixed-ligand coordination networks with rigid dicarboxylate and pyridine-n-aldoxime ligands. Impact of the second ligand in the structures' dimensionality and solvent capacity. Polyhedron 2017, 129, 9-21. [CrossRef]

61. Bacuom, E.I.; Drago, R.S. Nickel(II) and nickel(IV) complexes of 2,6-diacetylpyridine dioxime. J. Am. Chem. Soc. 1971, 93, 6469-6475. [CrossRef]

62. Pearse, G.A., Jr.; Bovenzi, B.A. The synthesis and crystal structures of pyridine-2,6-dicarboxamide oxime, $\mathrm{C}_{7} \mathrm{H}_{9} \mathrm{~N}_{5} \mathrm{O}_{2}$, and its nickel(II) and copper(II) co-ordination compounds. J. Chem. Soc. Dalton Trans. 1997, 2793-2797. [CrossRef]

63. CrystalClear; Rigaku: The Woodlands, TX, USA; MSC Inc.: The Woodlands, TX, USA, 2005.

64. Sheldrick, G.M. A short history of SHELX. Acta Crystallogr. Sect. A 2008, 64, 112-122. [CrossRef]

65. Sheldrick, G.M. Crystal structure refinement with SHELXL. Acta Crystallogr. Sect. C 2015, 71, 3-8. [CrossRef]

66. Diamond, Crystal and Molecular Structure Visualization; Version 3.1; Crystal Impact: Bonn, Germany, 2018. 